\title{
THE
}

9-5-2013

\section{Climatic Variability of the Circulation in the Rhode Island Sound: A Modeling Study}

Yiyong Luo

University of Rhode Island

Lew Rothstein

University of Rhode Island, Irothstein@uri.edu

Qianqian Liu

Shuwen Zhang

Follow this and additional works at: https://digitalcommons.uri.edu/gsofacpubs

Terms of Use

All rights reserved under copyright.

\section{Citation/Publisher Attribution}

Luo, Y., L. Rothstein, Q. Liu, and S. Zhang (2013), Climatic variability of the circulation in the Rhode Island Sound: A modeling study, J. Geophys. Res. Oceans, 118, 4072-4091.

Available at: https://doi.org/10.1002/jgrc.20285

This Article is brought to you for free and open access by the Graduate School of Oceanography at DigitalCommons@URI. It has been accepted for inclusion in Graduate School of Oceanography Faculty Publications by an authorized administrator of DigitalCommons@URI. For more information, please contact digitalcommons-group@uri.edu. 


\title{
Climatic variability of the circulation in the Rhode Island Sound : A modeling study
}

\author{
Yiyong Luo, ${ }^{1,2}$ Lew Rothstein, ${ }^{1}$ Qianqian Liu, ${ }^{1}$ and Shuwen Zhang ${ }^{1}$ \\ Received 30 January 2013; revised 21 June 2013; accepted 21 June 2013; published 5 September 2013.
}

[1] Seasonal and interannual variability of the circulation in the Rhode Island Sound (RIS) is investigated by employing the Regional Ocean Modeling System (ROMS) with two configurations in which a local-scale model with very fine resolution over the RIS is nested within a regional-scale model covering the entire US Northeastern Continental Shelf. The models are driven by tidal harmonics, climatological river discharge, and realistic ocean open boundary conditions and atmospheric forcing from January 2004 to December 2009. Results show that the tidal residual current forms a cyclonic circulation in the RIS, with amplitude of a few centimeters per second. During summer, the cyclonic circulation is significantly strengthened owing to tidal mixing and local stratification. However, due to strong northwesterly winds in winter, the cyclonic circulation disappears and instead the surface currents in the RIS move offshore. Simulations further indicate that the RIS winter currents, in terms of their magnitude and direction, have interannual variability that appears to be related to the North Atlantic Oscillation (NAO) winter index. In addition, the southwestward jet near the southern New England shelf break is found to intensify (weaken) during the low (high) phases of the NAO with a lag of about 1 year. The ROMS models are also used to examine the response of the regional ocean circulation to global warming, with both atmospheric forcing and open boundary conditions obtained from global climate model outputs. As the climate warms, it is found that the cyclonic gyre in the RIS is intensified, and this change is due to an intensification of the larger-scale cyclonic coastal ocean circulation over the Middle Atlantic Bight in a warming climate.

Citation: Luo, Y., L. Rothstein, Q. Liu, and S. Zhang (2013), Climatic variability of the circulation in the Rhode Island Sound: A modeling study, J. Geophys. Res. Oceans, 118, 4072-4091, doi: 10.1002/jgrc.20285.

\section{Introduction}

[2] The Rhode Island Sound (RIS) is a semicircular embayment off the Southern Rhode Island and Massachusetts coast (Figure 1). It is partially bounded on the west by Point Judith and Block Island and on the east by Martha's Vineyard and the Elizabeth Islands. Its water is in free exchange with that of Block Island Sound (BIS) to the west, Narragansett Bay and the Sakonnet River to the north, Buzzards Bay and Vineyard Sound to the east, and the Atlantic Ocean continental shelf to the south.

[3] The RIS is an inshore temperate shelf area on the inner portion of the southern New England continental shelf. Ocean circulation of the broader southern New England shelf has received considerable attention with a well-

\footnotetext{
${ }^{1}$ Graduate School of Oceanography, University of Rhode Island, Narragansett, Rhode Island, USA.

${ }^{2}$ Physical Oceanography Laboratory, Ocean University of China, Qingdao, China.

Corresponding author: Y. Luo, Graduate School of Oceanography, University of Rhode Island, 215 South Ferry Rd., Narragansett, RI 02882, USA. (yluo@gso.uri.edu)

(C)2013. American Geophysical Union. All Rights Reserved. 2169-9275/13/10.1002/jgrc.20285
}

established baseline understanding [e.g., Beardsley and Boicourt, 1981; Ingham et al., 1982; Mountain, 2003; Lentz, 2008a, 2008b; Chen and He, 2010; Zhang et al., 2011]. In sharp contrast, relatively little appears to be known about the RIS; for example, in a recent review of Middle Atlantic Bight (MAB) observed mean circulation using all available archived mooring current meter records, the RIS area forms a somewhat conspicuous gap in coverage [Lentz, 2008a, Figure 1].

[4] Water on the southern New England shelf originates primarily from the Scotian shelf to the north [Chapman and Beardsley, 1989], and passes across Nantucket Shoals (adjacent the RIS to the southeast) generally after having passed through the Gulf of Maine and around or across Georges Bank. The polar origins, together with the effects of river and estuarine contributions, lead to shelf waters that are generally cooler and fresher on the inshore side of the shelf break front than the adjacent deep ocean slope water conditions to the south.

[5] The regional-scale long-term average circulation of the southern New England shelf is alongshore to the southwest, increasing in strength with distance offshore to reach $10-15 \mathrm{~cm} / \mathrm{s}$ in a jet centered near the shelf break [e.g., Lentz, 2008a]; it is typically strongest at the surface and weakens toward the seafloor. Spatial and temporal 


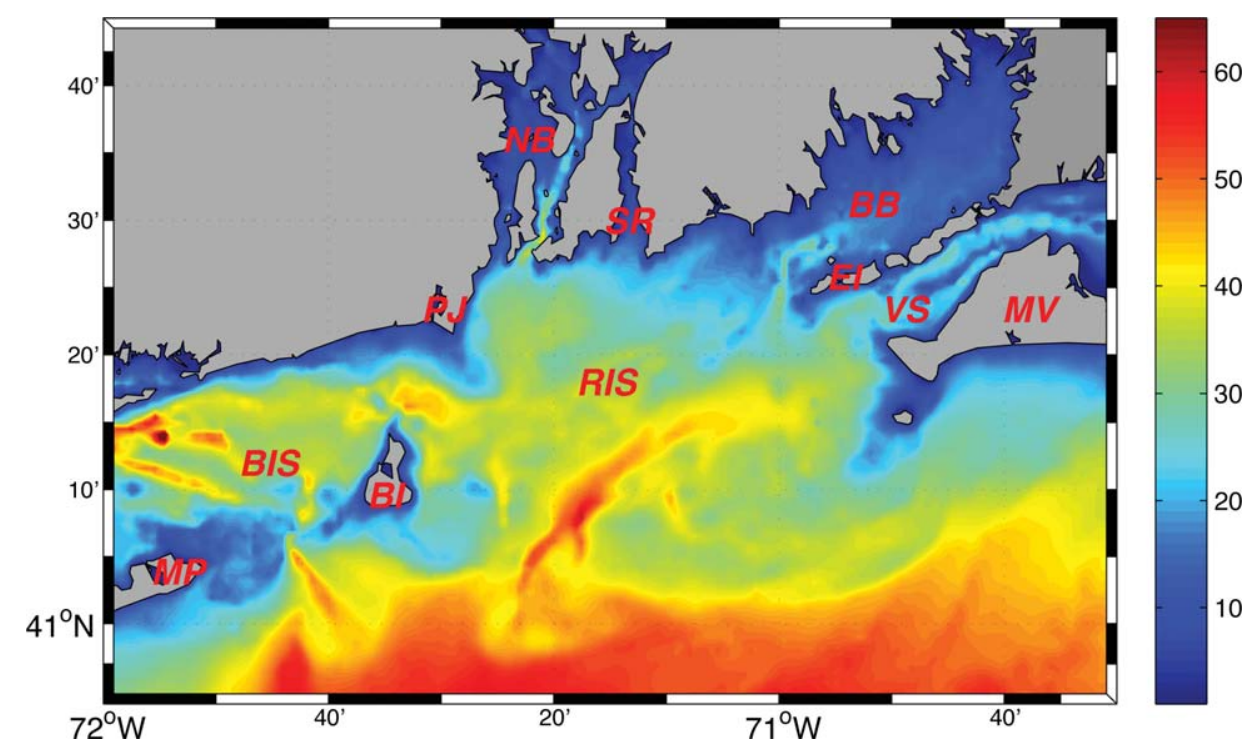

Figure 1. Bathymetry (color in $\mathrm{m}$ ) and geographic features around the Rhode Island Sound. Place names: Rhode island Sound (RIS), Block Island (BI), Montauk Point (MP), Block Island Sound (BIS), Point Judith (PJ), Narragansett Bay (NB), Sakonnet River (SR), Buzzards Bay (BB), Elizabeth Islands (EI), Vineyard Sound (VS), and Martha's Vineyard (MV).

variability of nontidal flow superposed on this broad mean circulation pattern is significant (typically 10 to $40 \mathrm{~cm} / \mathrm{s}$, but up to $80 \mathrm{~cm} / \mathrm{s}$ ) and results largely from wind fluctuations, coastal-origin flows emanating from rivers and estuaries, and interactions with Gulf Stream (GS) rings.

[6] Regarding the shallower shelf area within the RIS, our knowledge about its circulation pattern is much less but limited observations have revealed a jet-like current near the northern RIS coast with its strength strongest in summer and disappearing in winter [Kincaid et al., 2003; Ullman and Codiga, 2004]. It is not clear, however, if the causes of such seasonal variability of the current is driven locally or remotely. The local forcing may include winds, river discharge, stratification and tides. These forcing mechanisms have each been identified as important for shaping the seasonal changes to the circulations in the adjacent inner shelf bodies of water. For example, Ullman and Codiga [2004] find that a jet southwest of Block Island arises due to the shifting balance between buoyancy-driven flow (that is always downshelf but intensifies somewhat in summer) and wind-driven flow (which dominates in winter when wind stress becomes strongly upwelling favorable), whereas Edwards et al. [2004] conclude that the jet is a combination of tide-induced flow (nearshore) and buoyancy-driven flow (offshore). Tidal mixing and rectification are also found to contribute significantly to the coastal circulation in the upstream regions, i.e., Buzzards Bay and Vineyard Sound [e.g., Sankaranarayanan, 2007] and West of Martha's Vineyard [e.g., Wilkin, 2006; He and Wilkin, 2006].

[7] In addition to these local dynamics, the flow in the RIS is likely part of the larger-scale cyclonic coastal ocean circulation over the MAB. Measurements of the annual mean circulation clearly demonstrate that the along-shelf flow is directed toward the southwest through the MAB [Beardsley and Boicourt, 1981]. Driven primarily by an alongshore pressure gradient associated with the largescale wind stress and heat flux patterns over the region, this southwestward flow may be viewed as a boundary-layer component of the large-scale ocean general circulation of the western North Atlantic. Based upon this point of view, the observed flow in the RIS might plausibly be decomposed into a mean component driven by remote forcing and a fluctuating component driven by local forcing.

[8] In addition to seasonal variations, the circulation in the RIS may have significant variability on much longer time scales. The North Atlantic Oscillation (NAO) has been suggested as a natural mechanism for influencing the physical, biogeochemical and ecological environment off southern New England [e.g., Oviatt, 2004; Sullivan et al., 2005]. Variations in the NAO are associated with changes in the position of the GS, frequency of storm events, and patterns of temperature, winds, and precipitation during the year [Hurrell, 1995]. As such, all of these may play a role in influencing the seasonal-to-interannual circulation in the RIS.

[9] Coastal waters in southern New England have furthermore exhibited significant warming in the past few decades. For example, long-term data collected in Narragansett Bay have revealed trends of increasing water temperature, particularly in winter, and in the past 25 years winter water temperatures have increased by approximately $2^{\circ} \mathrm{C}$ [e.g., Nixon et al., 2004]. Accompanying this warming may also be a change in the circulation pattern of the southern New England shelf.

[10] For this study we employ a nested version of the Regional Ocean Modeling System (ROMS) to investigate the variability of the circulation in the RIS and to understand the processes that cause that variability. The numerical experiment design is described in section 2. Tidal-induced circulations are presented in section 3 . The model results are validated in section 4 . The seasonal and interannual 


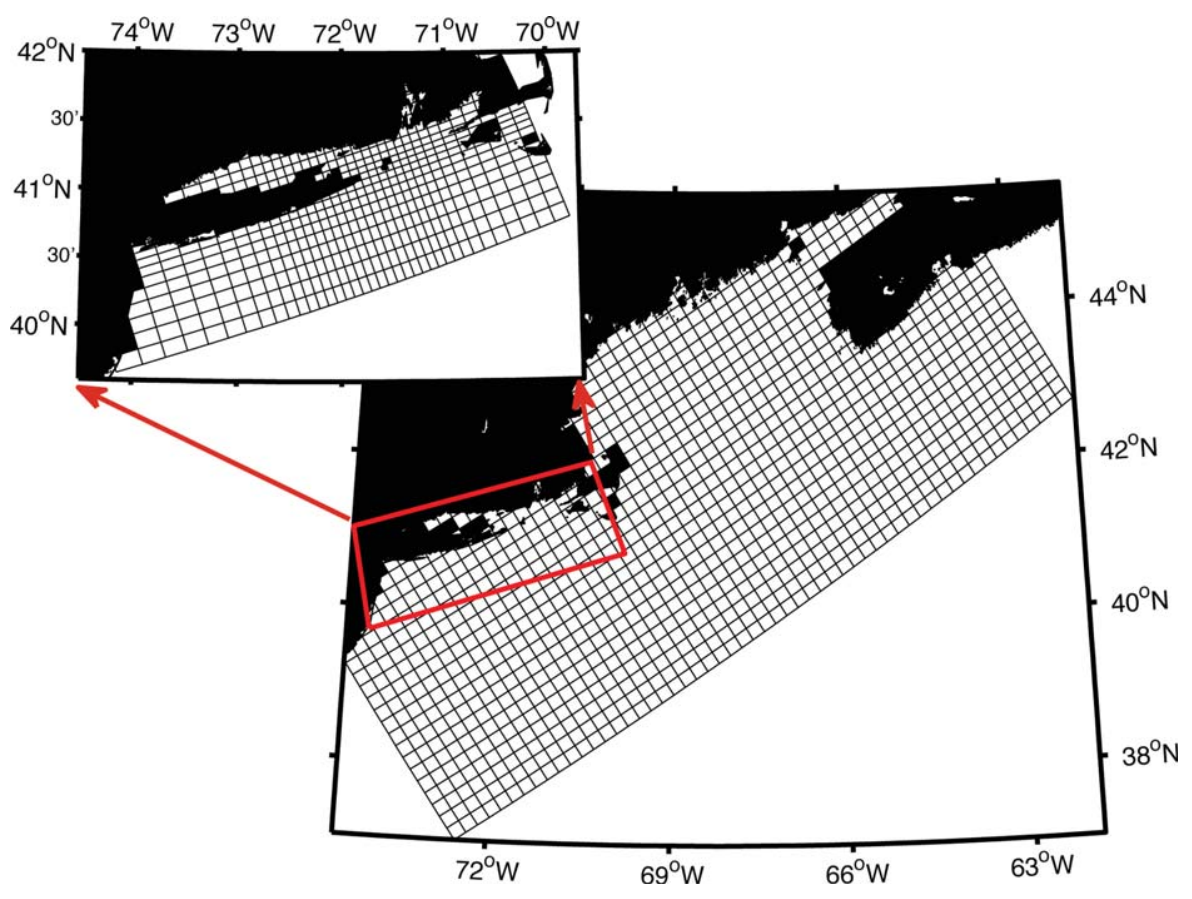

Figure 2. Model configurations. The local-scale ROMS grid (plotted every 8 grid points) varies from $600 \mathrm{~m}$ over the RIS and BIS to $\sim 1 \mathrm{~km}$ along the boundaries. The regional-scale ROMS grid (plotted every 4 grid points) is uniform with a resolution of $5 \mathrm{~km}$.

variability of the circulation is examined in sections 5 and 6 , respectively. Section 7 explores the response of the circulation to global warming, and a summary is given in section 8 .

\section{Design of Numerical Experiments}

[11] Numerical experiments are implemented using ROMS with two model configurations (Figure 2). A localscale ROMS is configured for the domain including the RIS, the BIS, the Long Island Sound (LIS) and the adjacent inner shelf area, with a horizontal grid varying from $600 \mathrm{~m}$ over the RIS and BIS to $1 \mathrm{~km}$ along the boundaries. A regional-scale ROMS grid covers the Gulf of Maine/ Georges Bank and New England shelf region and is enclosed by an open boundary from the New Jersey shelf to the Nova Scotia shelf, with a constant horizontal resolution of $5 \mathrm{~km}$. Both models have 15 terrain-following layers in the vertical, and the topography is derived from the $15 \mathrm{sec}-$ ond resolution bathymetry data from the Coastal Relief Model of the National Oceanic and Atmospheric Administration's Geophysical Data Center. The local-scale ROMS is one-way nested within the regional-scale ROMS for specifying its open boundary conditions.

[12] The open boundary conditions for the regional-scale ROMS are derived from a global eddy resolving model simulation produced by the Hybrid Coordinate Ocean Model (HYCOM)/Navy Coupled Ocean Data Assimilation (NCODA). HYCOM/NCODA provides daily threedimensional ocean state variables at a resolution of $1 / 12^{\circ}$ in both longitude and latitude and 32 vertical layers. The output used for this study spans 6 years from January 2004 to December 2009, and a monthly climatology of each variable (velocity, temperature, and salinity) is also obtained to use as boundary conditions for the model's spinup run. Specifically, for tracers and baroclinic velocity we apply radiation conditions with nudging toward HYCOM/NCODA solutions; the nudging time scale varies linearly from 5 to 60 days over an eight gridpoint wide buffer zone along the open boundaries. For both the free surface and depth-averaged velocity we use the method of Flather [1976] with external subtidal values defined by HYCOM/NCODA plus tidal harmonics from five tidal constituents $\left(\mathrm{M}_{2}, \mathrm{~N}_{2}, \mathrm{~S}_{2}, \mathrm{O}_{1}, \mathrm{~K}_{1}\right)$ in an Advanced Circulation Model for Oceanic, Coastal and Estuarine Waters (ADCIRC) tidal simulation of the western Atlantic [Luettich et al., 1992]. The latter tidal input provides needed tidal mixing, which is an important element of the regional circulation [e.g., He and Wilkin, 2006; Chen and $\mathrm{He}, 2010]$. In addition, we choose a quadratic drag formulation for bottom stress, and the Mellor-Yamada Level 2.5 turbulence closure for vertical mixing.

[13] Monthly surface atmospheric forcing fields (including winds, air temperature, air pressure, relative humidity, rainfall rate, short wave, and long wave radiations) are obtained from a new National Centers for Environmental Prediction (NCEP) global reanalysis [Saha et al., 2010], which is available in a resolution of $0.5^{\circ}$ longitude $\times 0.5^{\circ}$ latitude. To serve as surface forcing conditions for the spinup runs, a monthly climatology of each field is also derived with the new NCEP data from January 2004 to December 2009. Bulk formulae are used to calculate latent and sensible heat fluxes. For the long-term computations, in order to constrain the drift of surface flux, the common practice is to relax temperature and salinity to their observed values. Here for the regional-scale ROMS, we implement a thermal correction following He and Weisberg [2002]: 
Table 1. List of Experiments with ROMS

\begin{tabular}{|c|c|c|c|c|}
\hline \multirow[b]{2}{*}{ Name } & \multicolumn{3}{|c|}{ Forcing } & \multirow[b]{2}{*}{ Motivation } \\
\hline & Tides (M2, S2, N2, O1, K1) & $\begin{array}{c}\text { Climatological River } \\
\text { Discharges }\end{array}$ & $\begin{array}{c}\text { Oceanic and } \\
\text { Atmospheric Forcing } \\
\text { Fields }\end{array}$ & \\
\hline TIDE & Yes & No & No & Tidal residual current \\
\hline REAL & Yes & Yes & Yes $^{\mathrm{a}}$ & Seasonal and interannual variability \\
\hline REAL-NoR & Yes & No & Yes $^{\mathrm{a}}$ & Role of river discharge \\
\hline REAL-NoRT & No & No & $\mathrm{Yes}^{\mathrm{a}}$ & Role of tides \\
\hline CTRL & Yes & Yes & Yes $^{\mathrm{b}}$ & Control run \\
\hline WARM & Yes & Yes & $\mathrm{Yes}^{\mathrm{c}}$ & Response to global warming \\
\hline
\end{tabular}

a Atmospheric surface forcing from 2004 to 2009 in NCEP and oceanic open boundary conditions from 2004 to 2009 in HYCOM/NCODA.

${ }^{\mathrm{b}}$ Both atmospheric surface forcing and oceanic open boundary conditions from 1991 to 2000 in 20C3M from MIROC3.2.

${ }^{\mathrm{c} B}$ Both atmospheric surface forcing and oceanic open boundary conditions from 2091 to 2100 in SRESA1B from MIROC3.2.

$$
K_{H} \frac{\partial T}{\partial Z}=\frac{Q}{\rho C_{p}}+\mathrm{c}\left(T_{o b s}-T_{\mathrm{mod}}\right)
$$

where $K_{H}$ is the vertical diffusivity coefficient, $Q$ is the net heat flux, $\rho$ and $C_{p}$ are the seawater density and specific heat capacity, respectively. The relaxation coefficient, $\mathrm{c}=0.8 \mathrm{~m} /$ day, represents the reciprocal of the restoring time per unit area, and $T_{o b s}$ is the daily blended cloud-free sea surface temperature from the Jet Propulsion Laboratory (http://mur.jpl.nasa.gov/index.php). In addition, the sea surface salinity is restored to a monthly climatology from HYCOM.

[14] Fresh water outflow is incorporated using the United States Geological Survey (USGS) stream gauge data from 15 major rivers. These are, from south to north, Hudson River, Housatonic River, Connecticut River, Pawcatuck River, Pawtuxet River, Blackstone River, Taunton River, Neponset River, Merrimac River, Saco River, Androscoggin River, Kennebec River, Penobscot River, St. Croix River, and St. Johns River. In these experiments, the barotropic and baroclinic time steps are 10 and $300 \mathrm{~s}$, respectively, for the regional-scale ROMS, and are 5 and $150 \mathrm{~s}$, respectively, for the local-scale ROMS.

[15] Initialized with a resting ocean and with temperature and salinity set to the January climatologies, the models are first spun up with the monthly climatological forcing for 5 years, and then integrated with the surface and open boundary forcing from January 2004 to December 2009. We label this set of experiments as "REAL" (Table 1), with results to be presented in sections 5 and 6 .

[16] In addition to the REAL experiments we have also performed a pair of experiments with the ROMS models to examine the response of the oceanic circulation to global warming in which both atmospheric forcing and open boundary conditions are obtained from the MIROC3.2 model of the Fourth Assessment Report (AR4) of the Intergovernmental Panel on Climate Change (IPCC). This model's ocean component has the highest horizontal resolution $\left(0.28^{\circ}\right.$ longitude $\times 0.18^{\circ}$ latitude $)$ of the entire collection of IPCC AR4 coupled models available from the Program for Climate Model Diagnosis and Intercomparison (PCMDI) data center. Specifically, simulations from 1991 to 2000 in 20C3M are selected to represent the present-day climate, and simulations from 2091 to 2100 in SRESA1B represent the future climate. The $20 \mathrm{C} 3 \mathrm{M}$ experiments simulate the 20th century climate where atmospheric $\mathrm{CO}_{2}$ concentrations and other input data are based on historical records. The SRESA1B scenarios represent a climate in which atmospheric $\mathrm{CO}_{2}$ concentrations double their present-day level in the year 2100. This pair of experiments are called "CTRL" and "WARM" (Table 1), respectively, and results from them will be examined in section 7 .

[17] Another experiment is configured for verifying model fidelity and for testing our hypothesis regarding the cyclonic circulation in the RIS. For this experiment we isolate tidal forcing from all other forcing in which tidal harmonics are applied to the model open boundaries and the ocean is configured with constant temperature $\left(14^{\circ} \mathrm{C}\right)$ and salinity (35 psu). We call this experiment "TIDE" (Table $1)$, and its results will be discussed in the next section.

\section{Tidal-Induced Circulation}

[18] There are five tidal constituents $\left(\mathrm{M}_{2}, \mathrm{~N}_{2}, \mathrm{~S}_{2}, \mathrm{O}_{1}, \mathrm{~K}_{1}\right)$ in and around the RIS that represent $\sim 80 \%$ of the variance of the total depth-averaged tidal kinetic energy, with the $\mathrm{M}_{2}$ constituent dominating the energy (between $85 \%$ and 90\%) [Codiga and Rear, 2004]. As a result, evaluation of the tidal motion within the model is an important prerequisite to any model investigation.

[19] To verify the modeled tidal simulations we compare them with observations from tidal stations [Mau et al., 2007; Moody et al., 1984] and Coastal Ocean Dynamics Applications Radar (CODAR) [Ullman and Codiga, 2004], with the root-mean-square error (RMSE) used as a measure of precision. Table 2 lists both observed and modeled $\mathrm{M}_{2}$ amplitude and phase at 17 stations. It is found that the model results are in good agreement with the observations, with the RMSEs of the amplitude and the phase being about $4 \mathrm{~cm}$ and $6^{\circ}$, respectively. In addition, a comparison of surface tidal ellipses of $\mathrm{M}_{2}$ between the simulations and the observations further confirms the model's tidesimulating performance. In the offshore area (Figure 3a), the RMSE is about $2 \mathrm{~cm} / \mathrm{s}$ for both the semimajor and semiminor axes, with the discrepancy smaller south of the RIS than off Long Island. Similar errors in the latter region have been found in previous modeling works [Mau et al., 2007; Oey et al., 1995], and are attributed to surface wave contamination in the observations [Myers et al., 1990]. In and around the BIS (Figure $3 \mathrm{~b}$ ), the general structure of the 
Table 2. Comparison between Modeled and Observed Amplitude and Phase of the $\mathrm{M}_{2}$ Tidal Elevation at Stations Around the RIS

\begin{tabular}{|c|c|c|c|c|c|}
\hline \multirow{2}{*}{$\begin{array}{l}\text { Longitude } \\
\left({ }^{\circ} \mathrm{W}\right)\end{array}$} & \multirow{2}{*}{$\begin{array}{l}\text { Latitude } \\
\left({ }^{\circ} \mathrm{N}\right)\end{array}$} & \multicolumn{2}{|c|}{ Amplitude (m) } & \multicolumn{2}{|c|}{ Phase $\left(^{\circ}\right)$} \\
\hline & & Observed & Modeled & Observed & Modeled \\
\hline 70.67 & 41.63 & 0.54 & 0.52 & 8 & 0 \\
\hline 70.77 & 41.33 & 0.45 & 0.37 & 2 & -9 \\
\hline 71.05 & 41.15 & 0.44 & 0.42 & 1 & -3 \\
\hline 71.32 & 40.72 & 0.44 & 0.43 & -11 & -7 \\
\hline 71.33 & 41.50 & 0.51 & 0.49 & 1 & 0 \\
\hline 71.87 & 40.25 & 0.47 & 0.45 & -12 & -10 \\
\hline 71.82 & 41.08 & 0.34 & 0.34 & 11 & 1 \\
\hline 72.00 & 40.20 & 0.47 & 0.45 & -11 & -10 \\
\hline 72.25 & 40.65 & 0.50 & 0.47 & -14 & -12 \\
\hline 72.32 & 40.57 & 0.48 & 0.48 & -13 & -12 \\
\hline 72.92 & 40.12 & 0.53 & 0.52 & -12 & -11 \\
\hline 73.23 & 40.00 & 0.55 & 0.54 & -9 & -9 \\
\hline 73.57 & 40.13 & 0.59 & 0.58 & -10 & -9 \\
\hline 73.50 & 40.47 & 0.65 & 0.60 & -7 & -11 \\
\hline 72.09 & 41.36 & 0.37 & 0.36 & 58 & 44 \\
\hline 73.18 & 41.17 & 0.99 & 0.86 & 110 & 116 \\
\hline 73.77 & 40.81 & 1.14 & 1.12 & 116 & 125 \\
\hline
\end{tabular}

tidal flow is also well represented by the model, with the RMSE being about $2 \mathrm{~cm} / \mathrm{s}$ for the semimajor axis and 1 $\mathrm{cm} / \mathrm{s}$ for the semiminor axis. In addition to the $\mathrm{M}_{2}$ constituent, the modeled results of the other four tidal constituents $\left(\mathrm{N}_{2}, \mathrm{~S}_{2}, \mathrm{O}_{1}, \mathrm{~K}_{1}\right)$ are also consistent with the observations (Figures 3c-3f).

[20] Residual (rectified) currents, which are mostly generated by nonlinear interactions between the currents and topography, play an important role in the local circulation and net water transport. To extract the tidal residual currents (Figure 4), the model currents are averaged over the last month of the 4 month long run. To the south of Martha's Vineyard, there is a westward current with amplitude of a few centimeters per second. The westward current bifurcates in two directions in the southeast of the RIS: one branch moves continuously westward and one turns northward to form a cyclonic circulation in the RIS. To the southeast of Block Island, the two branches of the current join to move toward the southwest. To the northeast of Montauk Point, there is a relatively large amplitude eastward current in excess of $5 \mathrm{~cm} / \mathrm{s}$. When encountering Block Island, the current bifurcates with its southern branch reflected to the southwest, and its northern branch flowing into the RIS. The residual current forms an anticyclonic circulation pattern around Block Island. This is an important feature that our model captures, which is also observed in the modeling work of Edwards et al. [2004]. Another important feature captured by our model is an anticyclonic circulation to the southeast of Montauk Point, which is generally believed to be a headland eddy that is generated when strong currents pass the headland [e.g., Pingree and Maddock, 1979].

\section{Model Validation}

[21] Before presenting our model results on seasonal and interannual time scales, model solutions are first compared with the limited observations. Figure 5 shows a direct com- parison of mean depth-averaged shelf currents at 15 locations over the MAB between the model and the observations. The observations are from Lentz [2008a] in which he obtains the depth-averaged currents by analyzing current time series longer than 200 days. The model results are from Experiment REAL in which the mean currents are obtained by averaging the model integration period from 2004 to 2009. Both the observations and the model show that the mean velocities at all 15 sites are equatorward and approximately along-isobath, with larger speed of $\sim 10 \mathrm{~cm} /$ $\mathrm{s}$ on the outer shelf and smaller speed of about a few centimeter per second on the mid and inner shelf. While differences in both speed and direction are present for each pair of comparisons, the model overall does a good job, with the RMSEs of the speed and the direction being about 1 $\mathrm{cm} / \mathrm{s}$ and $10^{\circ}$, respectively. These differences could be due to the model resolution and topographic smoothing. Another comparison we have made between the model and the observations is the alongshelf volume transport at three cross-shelf transects within the MAB (Table 3). It is found that the model captures the alongshelf transport at the Georges Bank and Cape Cop transects reasonably well, but underestimates the transport at the Long Island transect. On average, the modeled transport appears to be $\sim 11 \%$ weaker compared with the observations.

[22] To further verify the modeled simulations we compare them with the observations at the central site of the Coastal Mixing and Optics Study (CMO) mooring array [Dickey and Williams, 2001]. Deployed on the New England shelf south of Cape Cop from August 1996 through June 1997, the CMO mooring observations span the seasonal stratification cycle and are the only long time series of conductivity throughout the water column with both along- and cross-isobath resolution on the New England shelf [Shearman and Lentz, 2003]. The CMO mooring array consist of four sites that are separated by about $10 \mathrm{~km}$. Here we choose the observations of currents from the densely instrumented central site (located at $40^{\circ}$ $29.5^{\prime} \mathrm{N}, 70^{\circ} 30.5^{\prime} \mathrm{W}$ with water depth of $70 \mathrm{~m}$ ) to validate our model results. Figure 6 shows seasonal mean currents at this site from the observations and the model. The mean currents are described in term of their along- and crossisobath components. The isobath angle is defined as a line running along $110 / 290^{\circ} \mathrm{T}$ in accordance with CMO publication convention. Positive along-isobath flow is roughly eastward and positive cross-isobath flow is roughly northward (on-shelf). In both the observations and the model, the mean along-isobath flow is westward at all depth and for all seasons, and its magnitude is largest in the fall and smallest in the spring and is the principal seasonal variation. In agreement with the observations, in addition, the modeled seasonal mean along-isobath currents reach their maxima at a depth of about 10-20 m but the cross-isobath flow is slightly stronger near the surface during winter resulting from a stronger wind stress [Shearman and Lentz, 2003]. Compared to the observations, however, the model has some discrepancies especially near the bottom in which the modeled currents appear to be weaker particularly during fall when the bottom cross-isobath flow moves on-shelf in the model while it is off-shelf in the observations. This is due in part to a relatively coarse vertical resolution near the bottom in the model. Table 4 presents the mean currents 
(a) $\mathrm{M}_{2}$

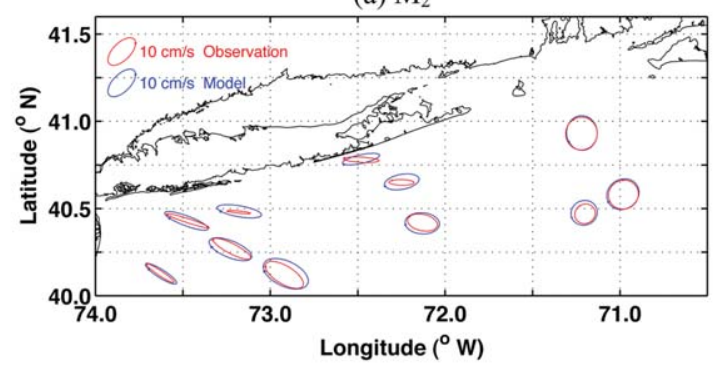

(b) $\mathrm{M}_{2}$
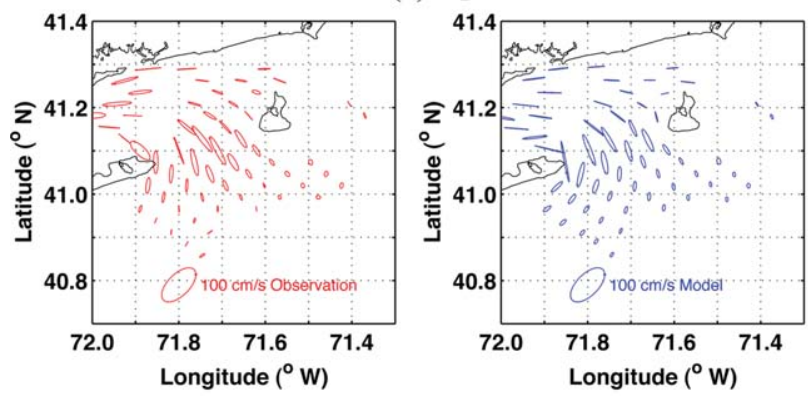

(c) $\mathrm{S}_{2}$
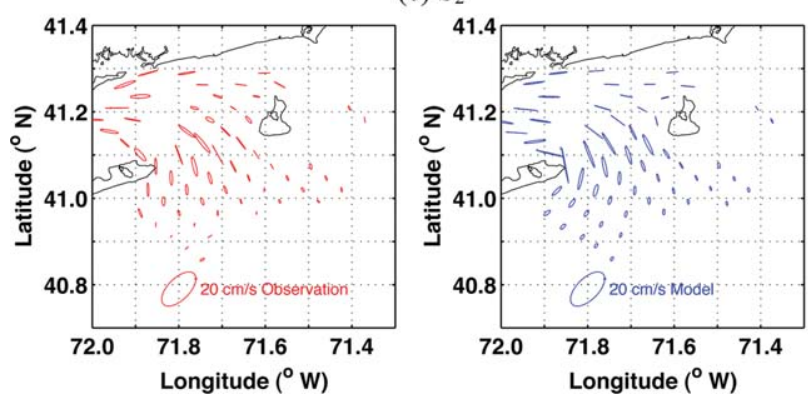

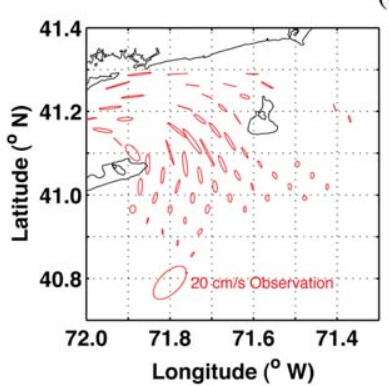

(d) $\mathrm{N}_{2}$

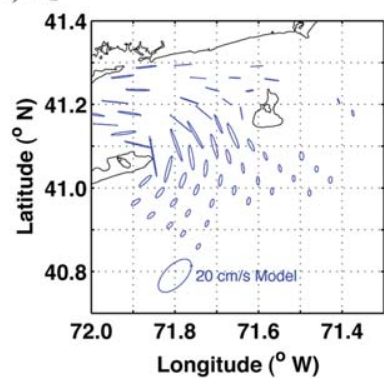

(e) $\mathrm{K}_{1}$
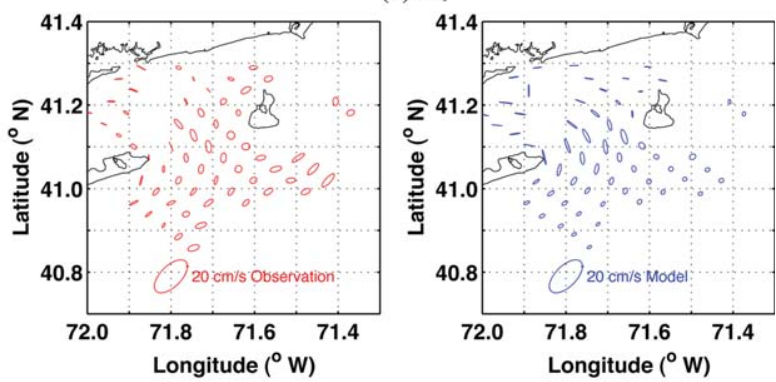

(f) $\mathrm{O}_{1}$

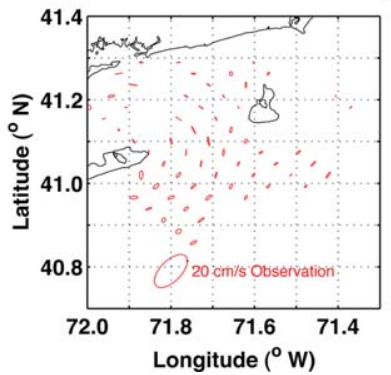

Figure 3. Comparison of tidal ellipses between the model (blue ellipses) and observations (red ellipses) from (a) current meter and (b-f) CODAR.

over the CMO period from the observations and the model. Again, it can be seen that the model has a better performance at the surface and middepth but significantly underestimates the magnitude of the flow near the bottom, leading to an underestimation of the depth-averaged flow at the location.

[23] On the New England inner shelf, our model results also show a reasonable agreement with the observations. Figure 7 compares the depth-averaged velocity fields in May in an area south of Block Island between the observations and the model. The velocity profile observations were obtained for the 2000-2001 period from the Front-Resolving Observational Network with Telemetry project [Ullman and Codiga, 2004]. The comparison shows that the model captures the southwestward motions at 9 out of 10 mooring stations, and the currents increase down-shelf (southwestward) from about $5 \mathrm{~cm} / \mathrm{s}$ to $10-15 \mathrm{~cm} / \mathrm{s}$ in both the observations and the model. The flow originating from the RIS strengthens southeast of Montauk Point because the outflow from the LIS joins it there [Ullman and Codiga, 2004].

[24] Mooring observations used to validate our model results on interannual time scales come from the Northeast- ern Regional Association of Coastal and Ocean Observing Systems (NERACOOS; http://neracoos.org/datatools/historical/graphing_download). In order to fit the model temporal coverage and to ensure the best availability of the observations in each depth, we select the mooring station B01 (located at $43^{\circ} 10.8^{\prime} \mathrm{N}, 70^{\circ} 25.6^{\prime} \mathrm{W}$ in the Western Maine shelf). In addition, a 30 day low-pass filter is applied to both modeled results and mooring observations. A comparison of observed and modeled velocity at a depth of 10 $\mathrm{m}$ is shown in Figure 8, where it can be seen that the model captures the seasonal and interannual variability of the velocity reasonably well. The model discrepancy is partly due to the model resolution and topographic smoothing. Figure 9 shows good agreement between the modeled and observed temperature with correlation coefficients over 0.9 at all three depths. While the implementation of the surface heat flux relaxation scheme effectively constrains surface temperature from drifting, the fact that the model generally tracks subsurface temperatures (i.e., 20 and $50 \mathrm{~m}$ ) suggests that the turbulence and advection processes are realistically simulated by the model. In addition to the model resolution, the discrepancy may be also due to the surface forcing 


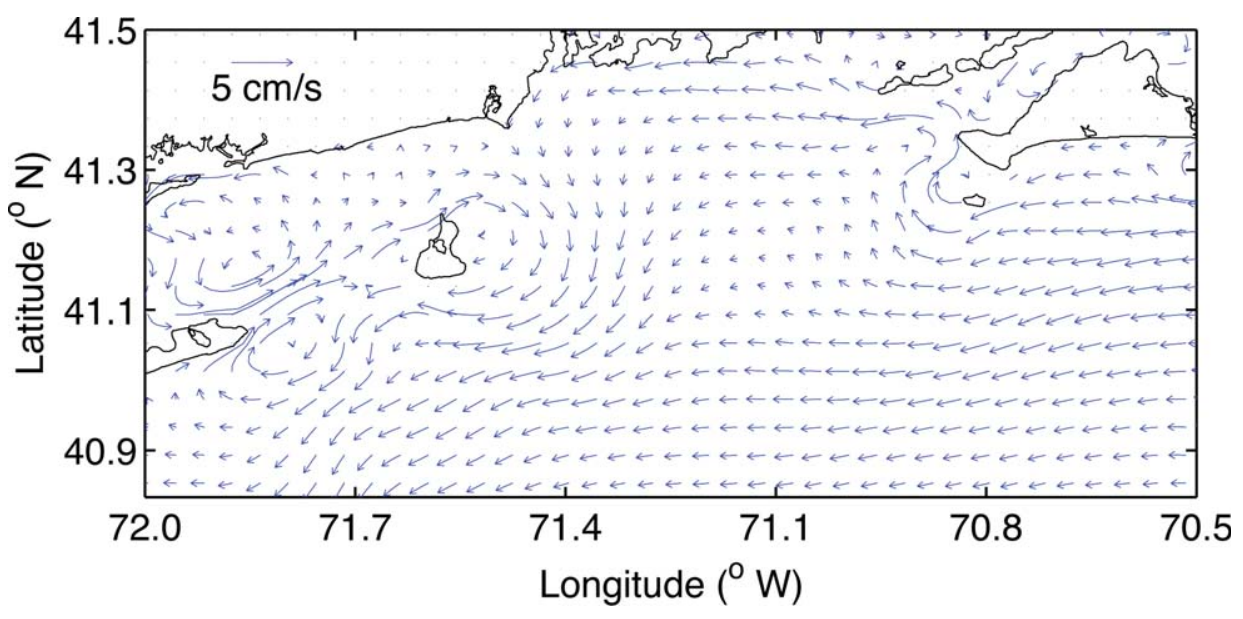

Figure 4. Depth-averaged tidal residual currents from Experiment TIDE.

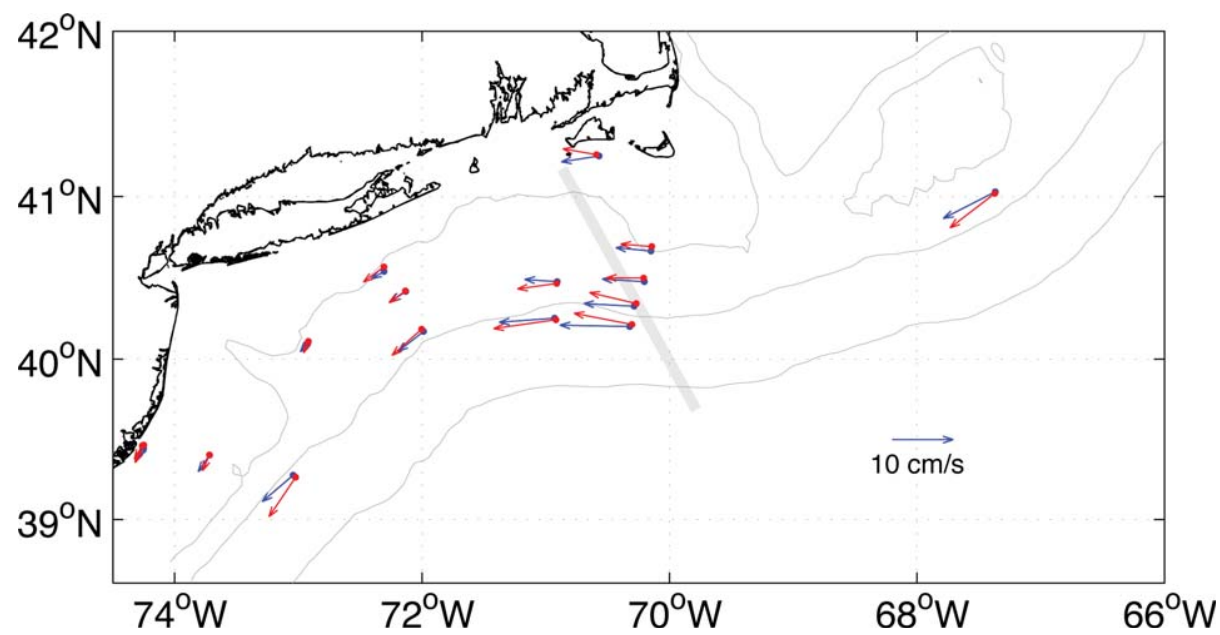

Figure 5. Comparison of mean depth-averaged currents between the model (blue arrows) and observations (red arrows). The modeled results are from Experiment REAL with the regional-scale ROMS, and the observations are from Lentz [2008a]. The thick gray line is the satellite track, along which the SSHA data were sampled. The 50,100, and $1000 \mathrm{~m}$ isobaths are also shown.

Table 3. Alongshelf Volume Transport at Three Cross-Shelf Transects Within the MAB

\begin{tabular}{|c|c|c|c|c|c|}
\hline Transect & Latitude $\left({ }^{\circ} \mathrm{N}\right)$ & Longitude $\left({ }^{\circ} \mathrm{W}\right)$ & Shelfbreak Depth (m) & Observed Transport $\left(10^{6} \mathrm{~m}^{3} \mathrm{~s}^{-1}\right)$ & Modeled Transport $\left(10^{6} \mathrm{~m}^{3} \mathrm{~s}^{-1}\right)$ \\
\hline Georges Bank & $41^{\circ} 17^{\prime}$ & $67^{\circ} 43^{\prime}$ & 95 & 0.44 & 0.42 \\
\hline Cape Cod & $41^{\circ} 20^{\prime}$ & $70^{\circ} 33^{\prime}$ & 125 & 0.64 & 0.61 \\
\hline
\end{tabular}

${ }^{\mathrm{a}}$ The position of the coastal end of each transect and the water depth at the shelf break are also listed. The modeled results are from Experiment REAL with the regional-scale ROMS, and the observations are from Lentz [2008a].

where we have used monthly means instead of daily values. For salinity comparisons (not shown), we find that, while the model generally captures the observed 2004-2009 salinity variations, the discrepancy for salinity is more notable than that for temperature, with the largest difference being $\sim 3$ psu near the surface. Too coarse model resolution has been recognized as a problem for accurate salinity simulation [Fong and Geyer, 2002]. In addition, the model dis- crepancy is also due to the climatological river discharge that we have used for the simulation, because salinity at the mooring station B01 is tightly associated with river runoff, particularly the occasional strong rainfall. Such caveats leave room for future model improvement.

[25] Finally, we examine the model skill in reproducing the sea surface height. For model validation purposes, we obtain $1 / 3^{\circ} \times 1 / 3^{\circ}$ along-track sea surface height anomaly 


\section{(a) Observed from $\mathrm{CMO}$}
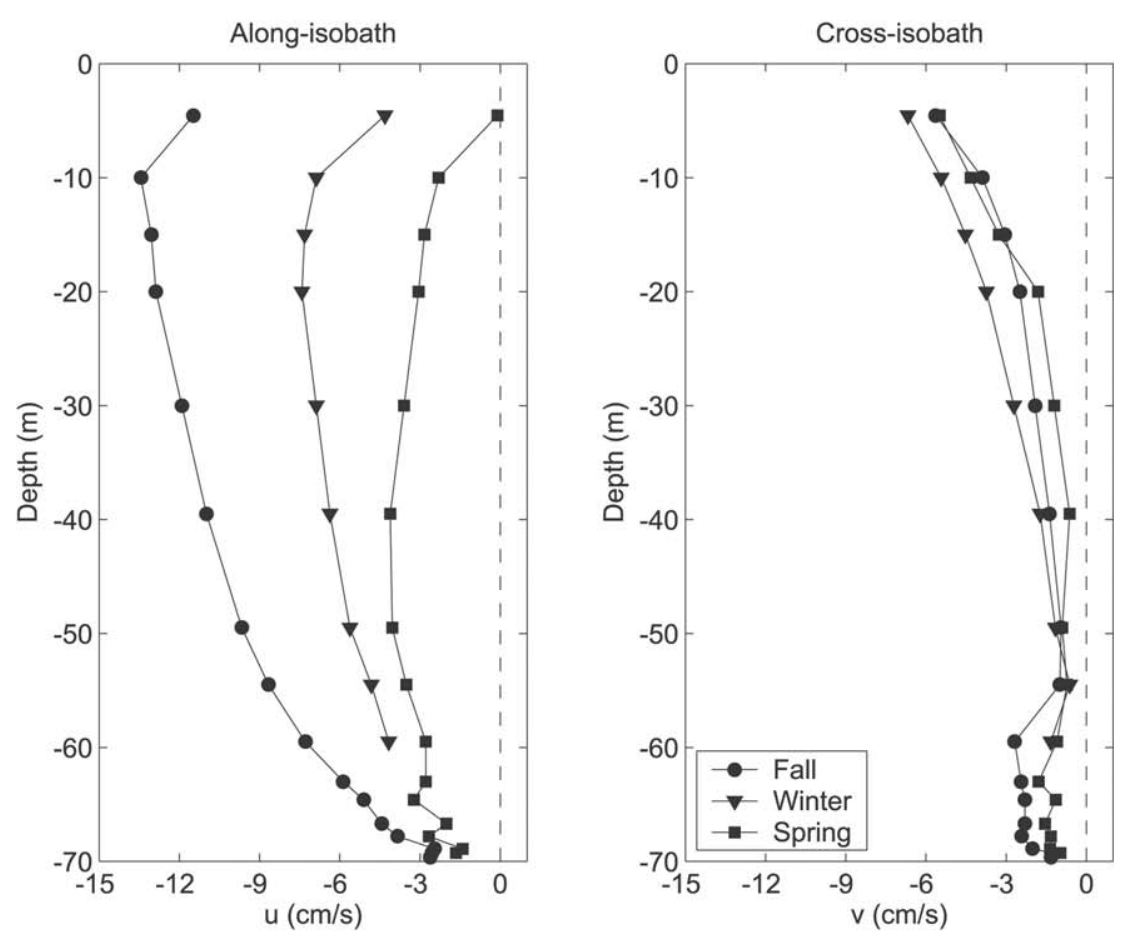

(b) Modeled from REAL
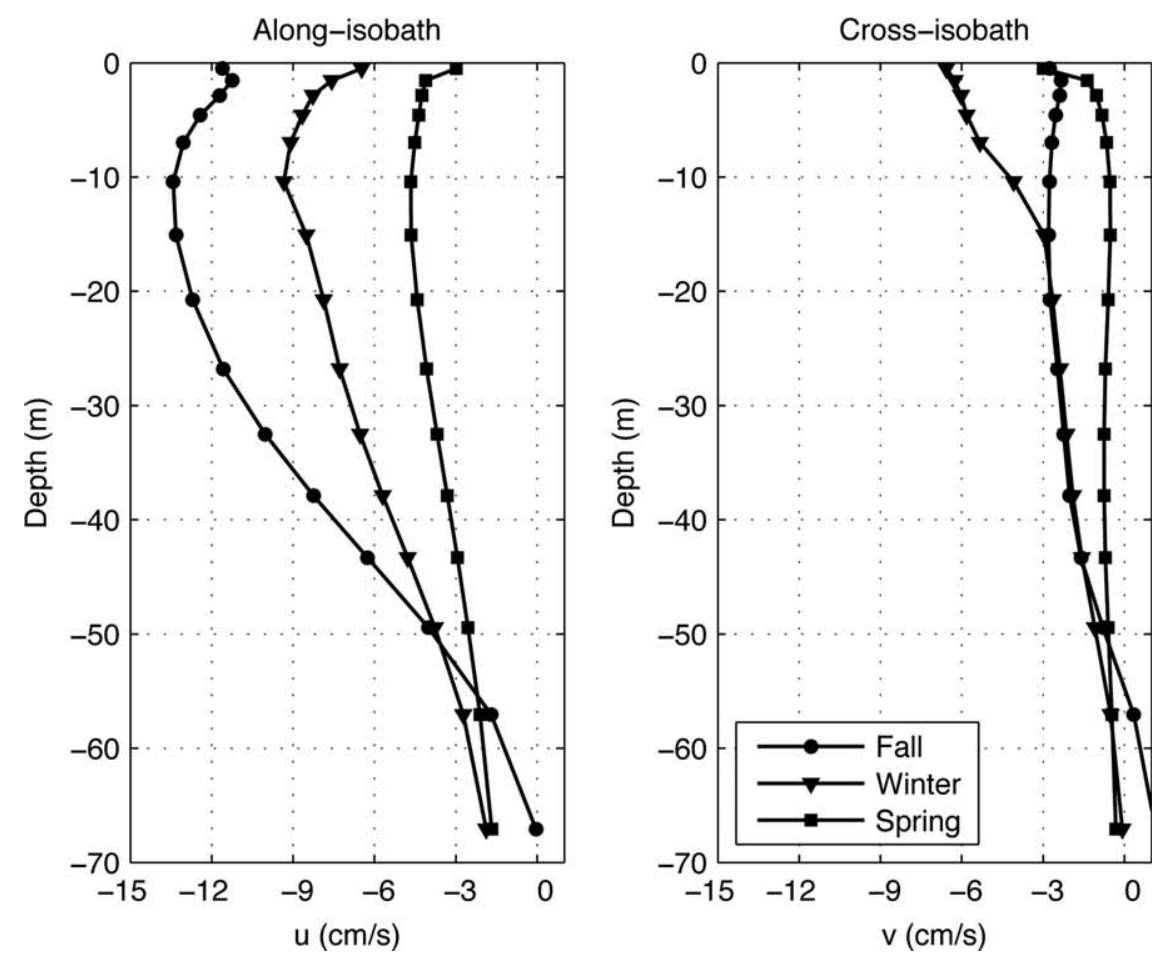

Figure 6. Profiles of the fall, winter, and spring along-isobath and cross-isobath mean currents at the CMO central site from: (a) observations [Shearman and Lentz, 2003] and (b) model (Experiment REAL).

(SSHA) from the Archiving, Validation, and Interpretation of Satellite Oceanographic data (AVISO) [Rio and Hernadez, 2004]. Three satellite tracks fall inside our regional- scale model domain. Among these, we select a cross-shelf track (thick gray line in Figure 5) that has the most coverage over the model domain and data available through the 
model integration period. In addition, because the alongtrack satellite data are only available every 9.9 days, for direct comparison we sample our modeled subtidal SSHA at the same time when altimeter observations are available. The Hovmöller diagrams of the satellite-observed and model-simulated SSHA along the selected track are shown in Figure 10. Along the track, both AVISO and ROMS indicate that large SSHA with a magnitude of up to $0.5 \mathrm{~m}$ occurs offshore near the Slope Sea, where energetic meanders and eddies often exert strong spatial-temporal influence on the shelf circulation. Although the model misses some of the fine-scale sea level structures, it captures the

Table 4. Subtidal Currents at the CMO Central Mooring Site ${ }^{a}$

\begin{tabular}{lll}
\hline & \multicolumn{2}{c}{ Mean } \\
\cline { 2 - 3 } Data & Magnitude $(\mathrm{cm} / \mathrm{s})$ & Direction $\left({ }^{\mathrm{o}} \mathrm{T}\right)$ \\
\hline Surface & & \\
Observed & 8.66 & 246 \\
Modeled & 9.72 & 260 \\
$30 m$ & & \\
Observed & 8.40 & 275 \\
Modeled & 8.23 & 276 \\
$60 m$ & & 270 \\
Observed & 5.35 & 285 \\
Modeled & 1.96 & 270 \\
Vertical Average & & 276 \\
Observed & 7.74 & \\
Modeled & 6.26 & \\
\hline
\end{tabular}

${ }^{\mathrm{a}}$ The modeled results are from Experiment REAL with the regionalscale ROMS, and the observations are from Cowles et al. [2008]. seasonal and interannual variability of the sea level reasonably well.

[26] These favorable model-observation comparisons discussed above suggest that the model is reliable for understanding the mean circulation and its seasonal and interannual variability (especially for the upper ocean) over the southern New England shelf and coastal regions.

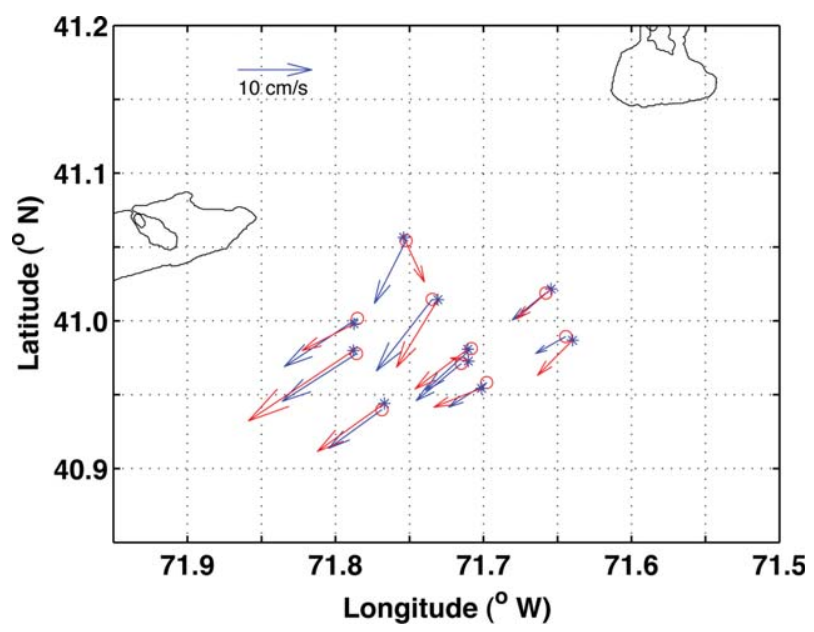

Figure 7. Comparison of the depth-averaged velocity fields in May between the model (blue arrows) and observations (red arrows). The modeled results are from Experiment REAL with the local-scale ROMS, and the observations are from Ullman and Codiga [2004].
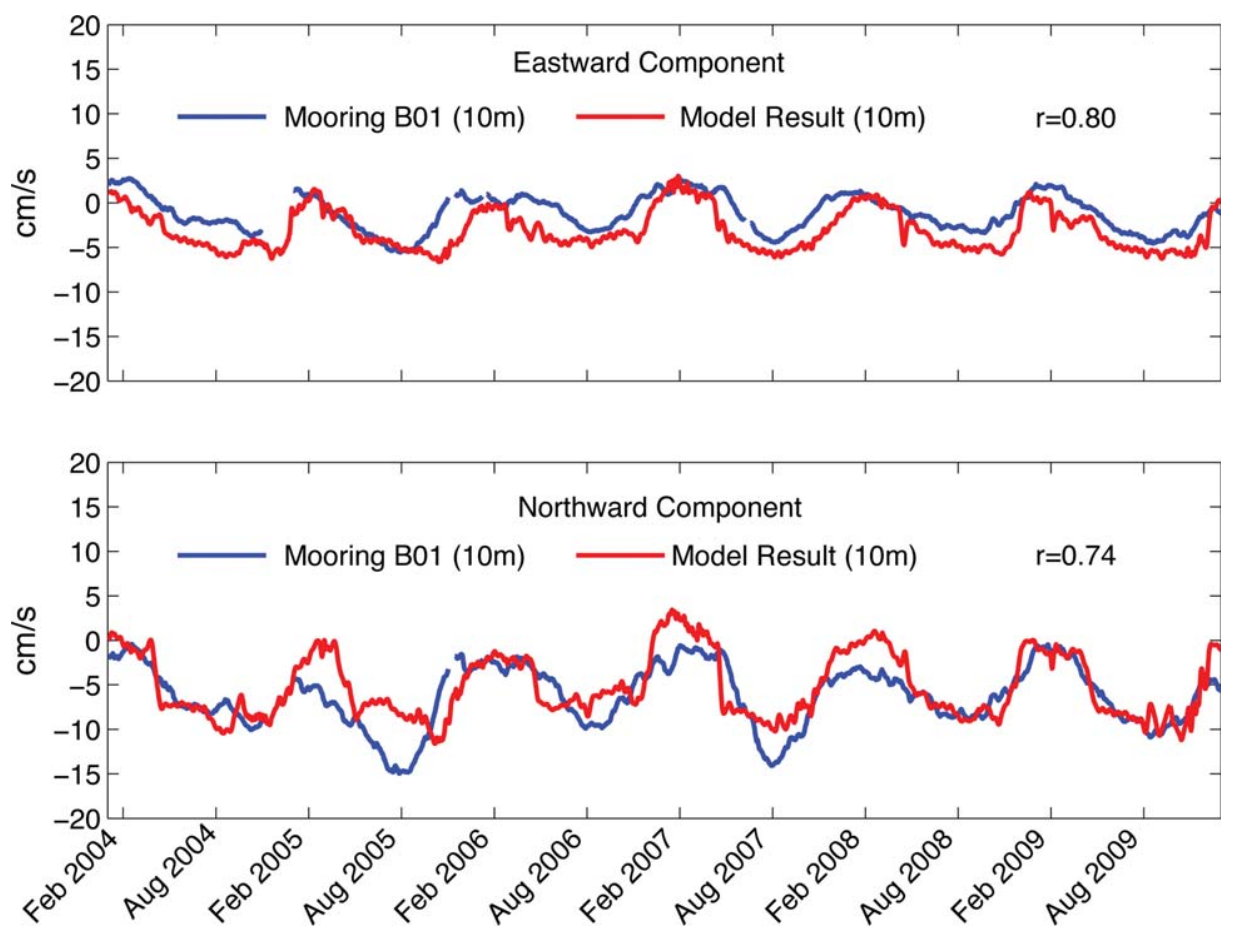

Figure 8. Comparison of observed and simulated velocity time series at NERACOOS mooring station B01. 

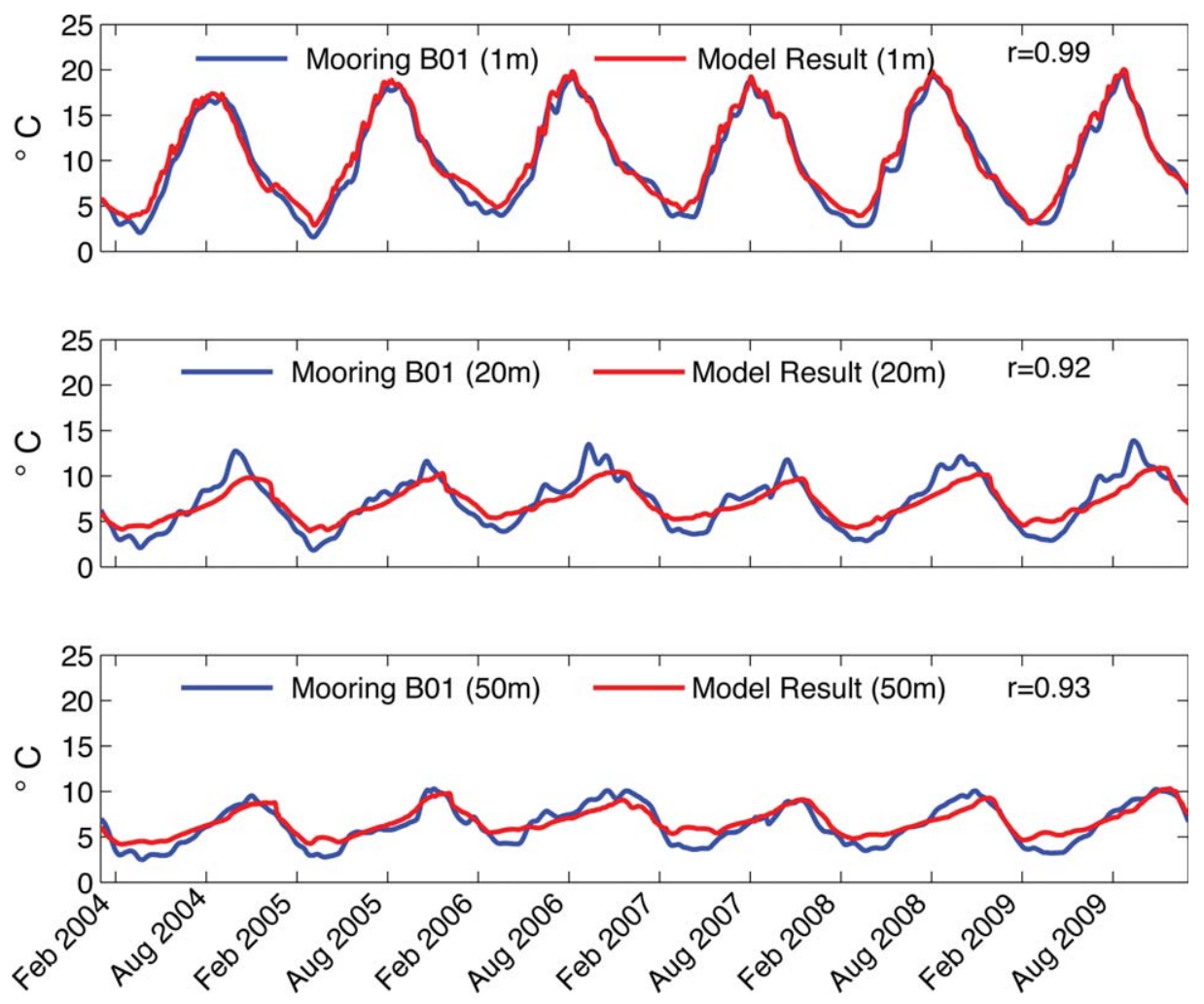

Figure 9. Comparison of observed and simulated temperature time series at NERACOOS mooring station B01.

\section{Seasonal Variability of the Circulation}

[27] Monthly and annual mean velocity fields are obtained from the output of the REAL experiment. Figures 11 and 12 show the annual mean surface circulation as well as its seasonal variability from the regional-scale and localscale model simulations, respectively. Consistent with previous studies, regional features of the surface annual mean circulation over the US Northeastern Continental Shelf (Figure 11a) include a flow entering the Gulf of Maine from the Scotia shelf, a cyclonic circulation in the Gulf of Maine, an anticyclonic circulation on the Georges Bank, and a southwestward alongshelf flow on the southern New England shelf. This alongshelf mean flow over the outer shelf (at depths greater than $\sim 50 \mathrm{~m}$ ) appears to increase with increasing depth and reaches $\sim 10 \mathrm{~cm} / \mathrm{s}$ around the $100 \mathrm{~m}$ isobath. On the inner shelf off southern New England (Figure 12a), the alongshelf mean flow is generally a few centimeters per second with a maximum of $\sim 20 \mathrm{~cm} / \mathrm{s}$ to the southeast of Montauk Point. This local increased alongshore circulation could be caused by the strong tidal residual currents there as discussed above (see Figure 4) and/or the freshwater discharge from the Connecticut River, and will be investigated later in this section. In addition, the surface mean flow also features a weak cyclonic circulation within the RIS and a strong anticyclonic circulation around Block Island.

[28] Seasonal variations of the surface circulation appear to be significant over the entire US Northeastern Continental Shelf (Figures 11b-11e). In the Gulf of Maine, the cyclonic circulation is present throughout the year but appears to be stronger during winter. On the Georges Bank, the anticyclonic circulation is weaker during winter and spring and is stronger during summer and fall, with more significant changes over the northern flank of Georges Bank. Over the southern New England shelf region, the weak southwestward flow is strengthened during spring and summer, and becomes strongest in early fall, and is then weakened in winter. At the New England continental slope, the modeled southwestward jet appears strongest in March; this jet is believed to be dominated by relatively low-frequency processes originating in the open ocean such as GS warm core rings and topographic Rossby waves [e.g., Houghton et al., 1988; Beardsley et al., 1985; Linder and Gawarkiewicz, 1998; Fratantoni and Picket, 2003]. In the RIS (Figures 12b-12e), after a rapid intensification in spring, the cyclonic circulation becomes very strong (with a maximum of $\sim 10 \mathrm{~cm} / \mathrm{s}$ ) during summer and early fall, and then gradually weakens and disappears in winter when the surface currents appear offshore and southeastward. In addition, during late spring and early summer the southwestward currents to the southeast of Montauk Point reach a maximum $(\sim 25 \mathrm{~cm} / \mathrm{s})$, which may be associated with the freshwater discharge from the Connecticut River reaching a maximum then.

[29] To understand the seasonal variations of the circulation, a series of process-oriented numerical experiments with both the regional-scale and local-scale models are implemented to investigate the roles of various forcing mechanisms in shaping the seasonal changes to the circulation in and around the RIS. Removing the river discharge 

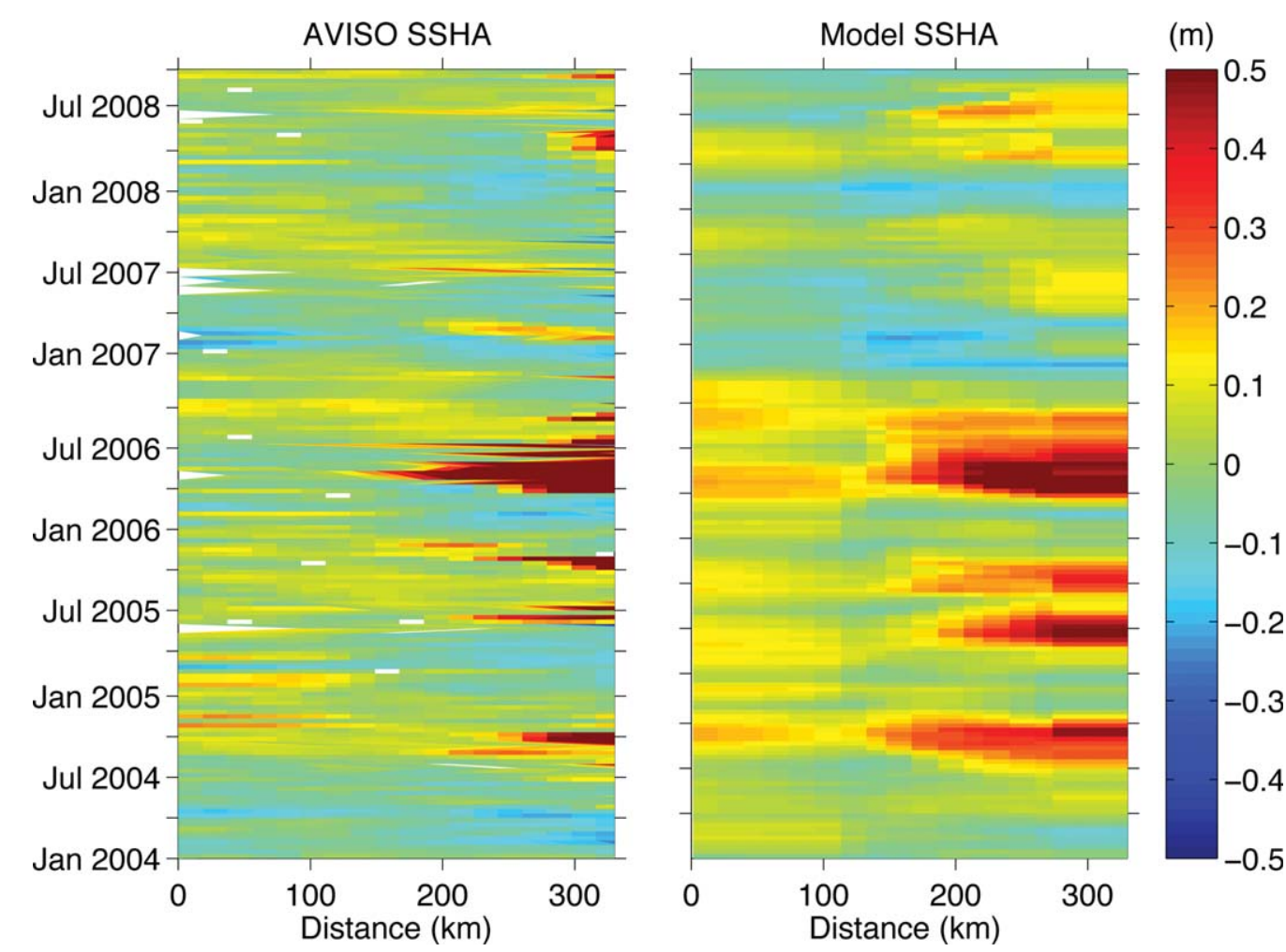

Figure 10. Hovmőller diagrams of satellite-observed and model-simulated SSHA along the cross-shelf transect for the period from January 2004 to October 2008.

along the coast (Experiment "REAL_NoR"; see Table 1), it is found (comparing Figure 13 with Figure 12) that while the cyclonic circulation in the RIS has changed little, the anticyclonic circulation around Block Island as well as the alongshore flow southeast of Montauk Point is significantly weakened, with the most significant weakening in spring thus confirming that the large flows observed there are indeed induced by the river discharge which reaches its maximum during spring. However, the influence of the river discharge is confined to the inner shelf area; there is no significant change in the circulation over the outer shelf region in the experiments without the river discharge (not shown).

[30] Further removing the tidal forcing from the experiments (Experiment "REAL_NoRT"; see Table 1), we find (comparing Figure 14 with Figures 12 and 13) that the general circulation signatures in and around the RIS disappear for all seasons. Instead, the surface flow is very sluggish in both spring and fall, and it appears offshore with its direction tending toward the east-southeast during summer and toward the south-southeast during winter. These circulation patterns are due mainly to wind forcing that is weak in spring and fall, and predominantly northeastward in summer and southeastward in winter. According to Ekman dynamics, a steady wind blowing across an unstratified ocean of unlimited depth and extent causes surface waters to move at an angle of $45^{\circ}$ to the right of the wind in the Northern Hemisphere. When the water depth is shallower than the Ekman depth, however, the surface flow steers to the right of the wind direction with a much smaller angle and even appears downwind near the coast. Based upon the definition of the Ekman layer depth $D_{E}=\frac{7.6}{\sqrt{\sin |\varphi|}} U_{10}$ [Steward, 2008], we find $D_{E}=47 \mathrm{~m}$ (here $\varphi=41^{\circ} \mathrm{N}$ is the latitude and $U_{10}=5 \mathrm{~m} / \mathrm{s}$ is the wind speed at $10 \mathrm{~m}$ above the sea) and that is larger than the water depth over the southern New England inner shelf.

[31] During summer, however, the effect of wind forcing near the Rhode Island coast is opposed by the geostrophic currents that are in balance with density difference between coastal and interior regions. Figure 15 shows the density and u-component of velocity (the velocity component perpendicular to the transect) fields in July along a section near the northern RIS coast (red line in Figure 12a) from the above three experiments. Consistent with observations [Kincaid et al., 2003], isopycnals dig downward from south to north across the northern RIS coastal region (Figures 15a and 15b), which results in a westward geostrophic current along the coast [e.g., Brooks, 1985]. Comparing Figure 15c with Figures $15 \mathrm{a}$ and $15 \mathrm{~b}$, it is clear that the tidal forcing is responsible for the strong westward velocity across the section during summer, with its volume transport being $1.48 \times$ $10^{4} \mathrm{~m}^{3} / \mathrm{s}$ in REAL and $1.35 \times 10^{4} \mathrm{~m}^{3} / \mathrm{s}$ in REAL_NoR, but only $0.58 \times 10^{4} \mathrm{~m}^{3} / \mathrm{s}$ in REAL_NoRT.

[32] Based upon our model simulations, we plot a schematic diagram in Figure 16 illustrating the surface circulation during summer in and around the RIS. A branch of the westward currents southwest of Martha's Vineyard turns northward and flows around the periphery of RIS to form a cyclonic circulation within the RIS. To the southeast of Block Island, the flow moves toward the southwest. In the BIS, an eastward current bifurcates 
(a) REAL: Annual Mean

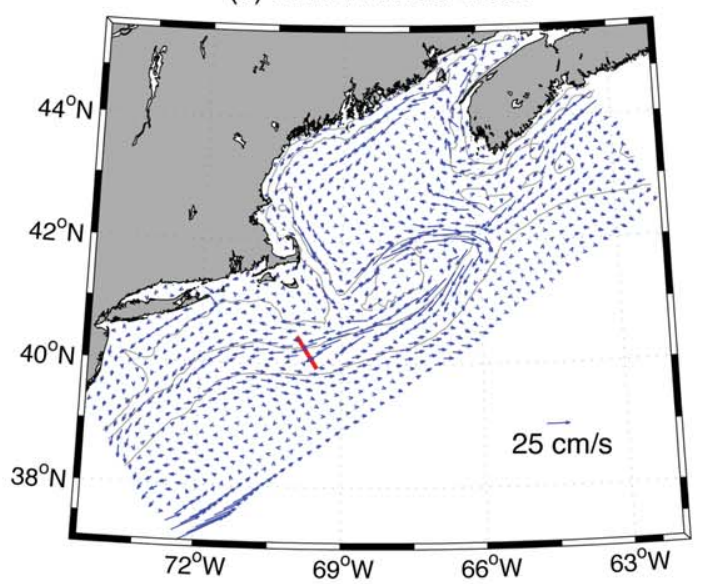

(b) REAL: March

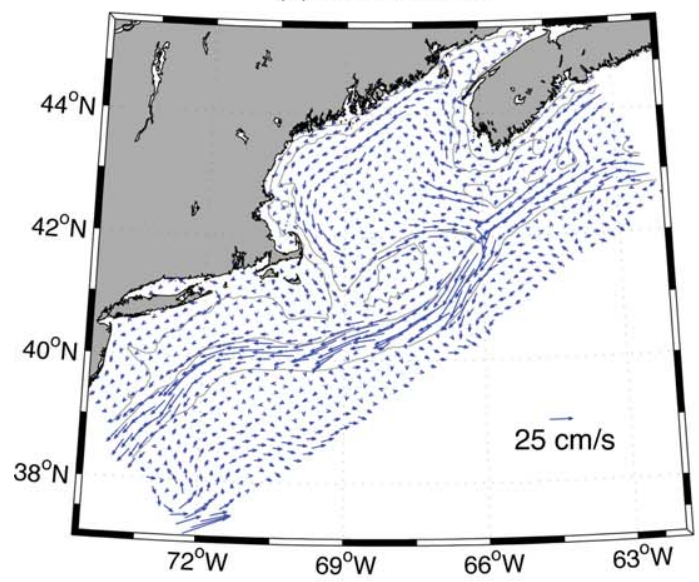

(d) REAL: September

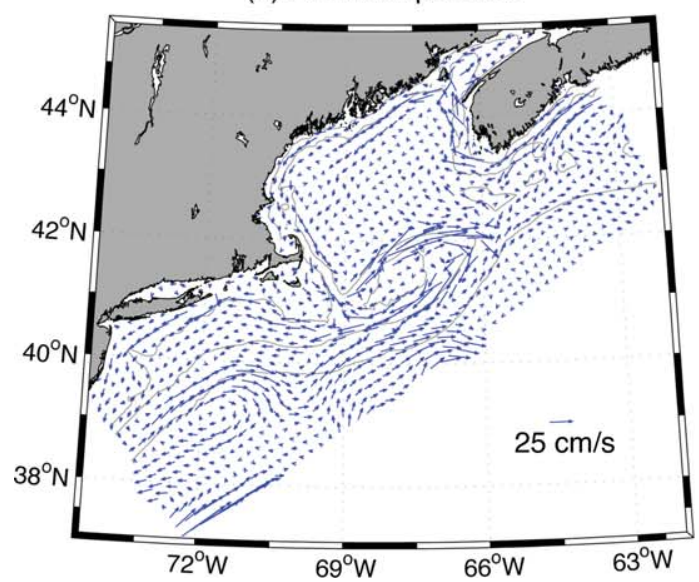

(c) REAL: June

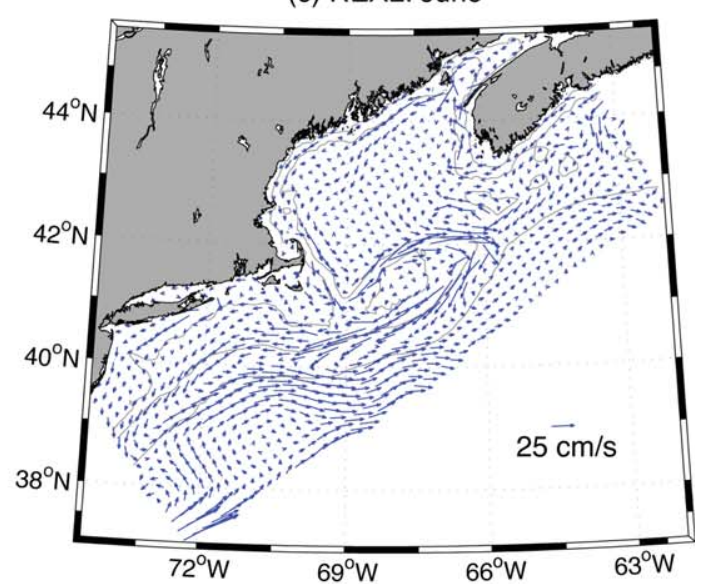

(e) REAL: December

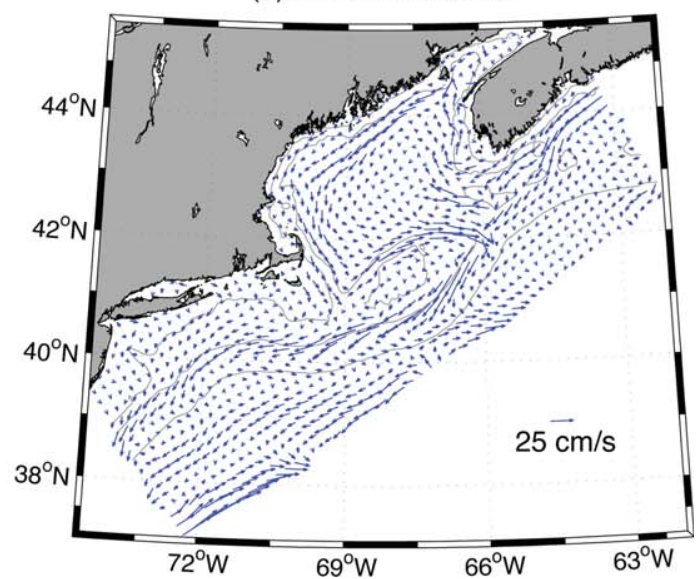

Figure 11. Surface velocity from Experiment REAL with the regional-scale ROMS : (a) Annual mean, (b) March, (c) June, (d) September, and (e) December. The thick red line in Figure 11a is the section referenced in Figure 17b. The 50, 100, and $1000 \mathrm{~m}$ isobaths are also shown.

before encountering Block Island; one branch continues to flow eastward into the RIS and forms an anticyclonic circulation around Block Island while another branch turns southward to flow out of the BLS and then moves southwestward alongshore. We note that this schematic is supported by the limited observations [Codiga, 2009; Codiga and Ullman, 2010].

[33] The process-oriented experiments above suggest that the cyclonic circulation within the RIS during summer is attributed to a combination of tidal forcing 
(a) REAL: Annual Mean

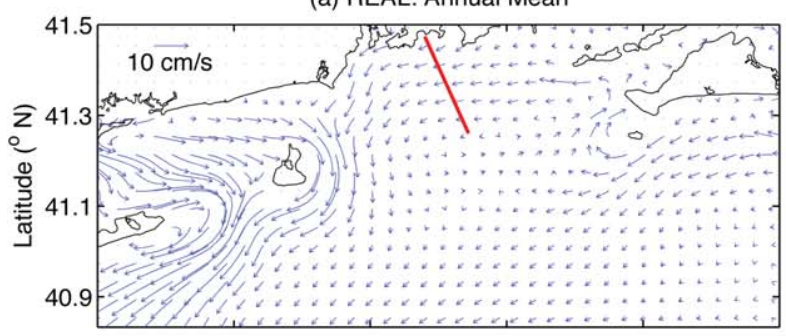

(b) REAL: March

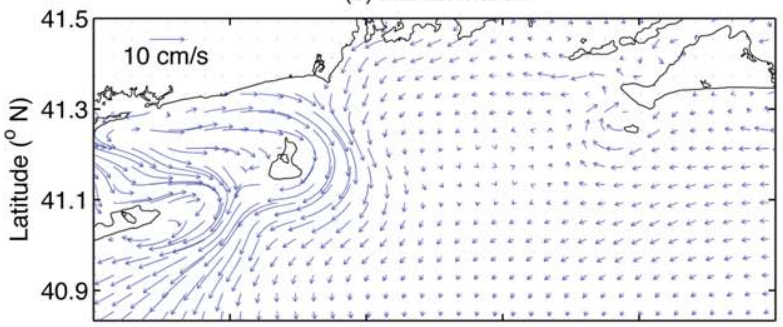

(c) REAL: June

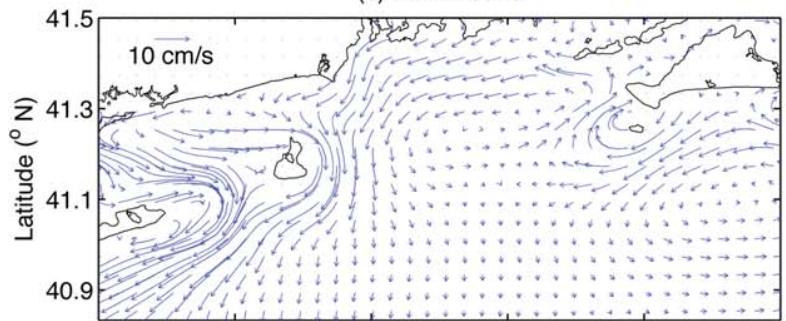

(d) REAL: September

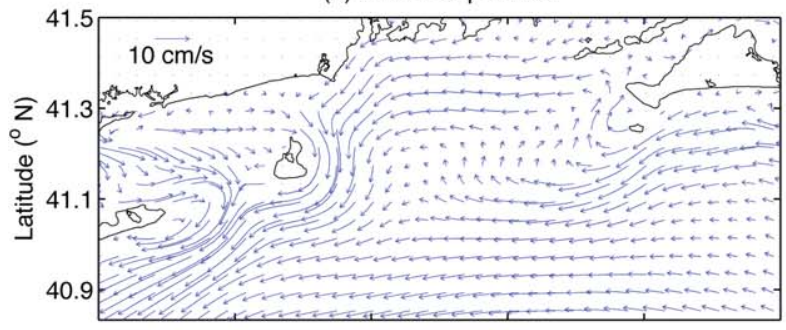

(e) REAL: December

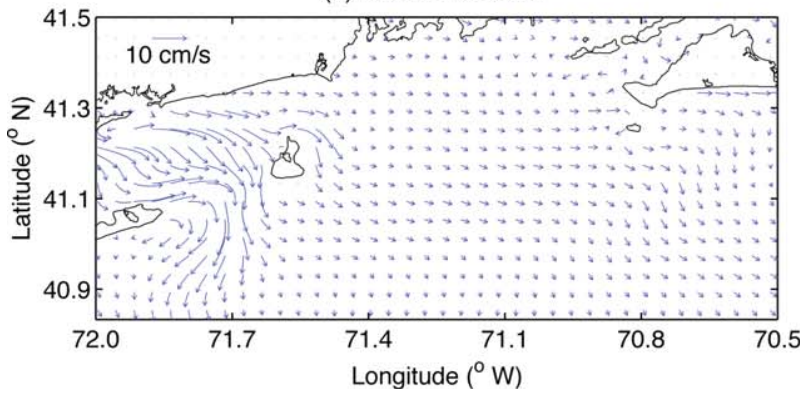

Figure 12. Surface velocity from Experiment REAL with the local-scale ROMS: (a) Annual mean, (b) March, (c) June, (d) September, and (e) December. The thick red line in Figure $12 \mathrm{a}$ is the section referenced in Figure 15.

and density differences between coastal and interior regions. The tidal forcing not only forms the residual current which directly contributes to the cyclonic circu- (a) REAL-NoR: Annual Mean

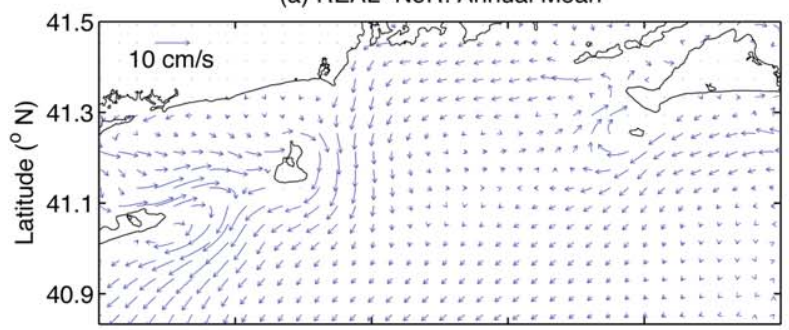

(b) REAL-NoR: March

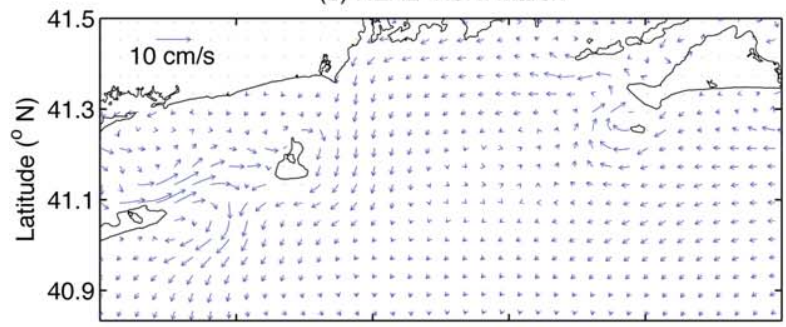

(c) REAL-NoR: June

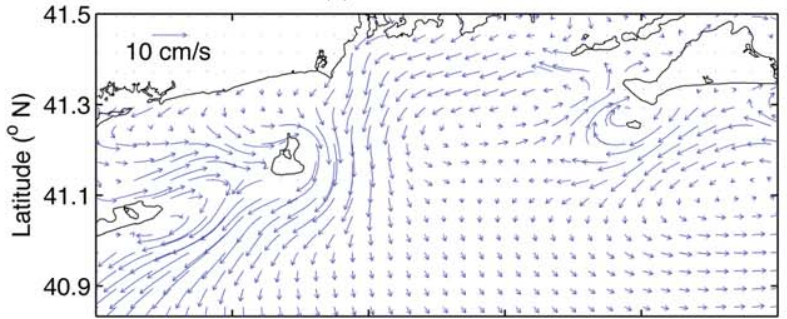

(d) REAL-NoR: September

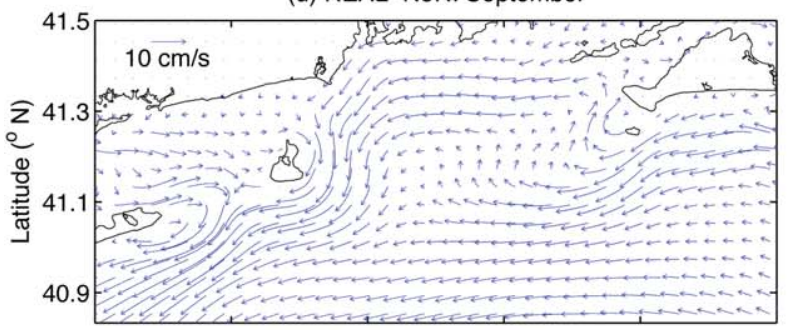

(e) REAL-NoR: December

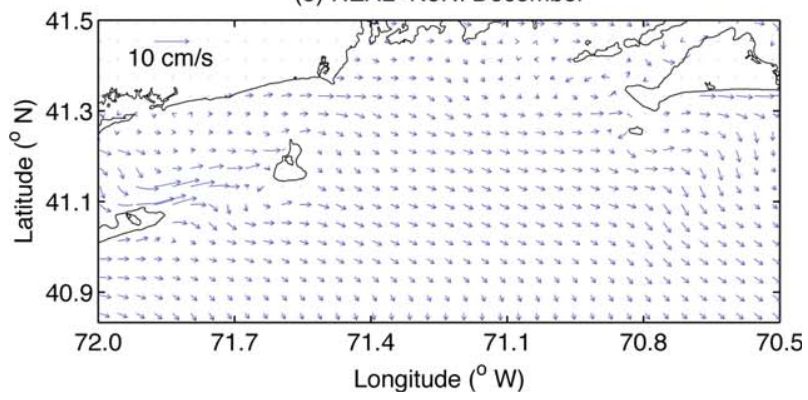

Figure 13. Same as Figure 12 but from Experiment REAL-NoR.

lation (see Figure 4), but also produces the mixing which plays a more important role for the cyclonic circulation (comparing Figure 14c with Figures 12c and $13 \mathrm{c}$, and Figure $15 \mathrm{c}$ with Figures $15 \mathrm{a}$ and $15 \mathrm{~b}$ ). During winter, the northwesterly winds turn the surface currents offshore. The freshwater discharge from the rivers 
(a) REAL-NoRT: Annual Mean

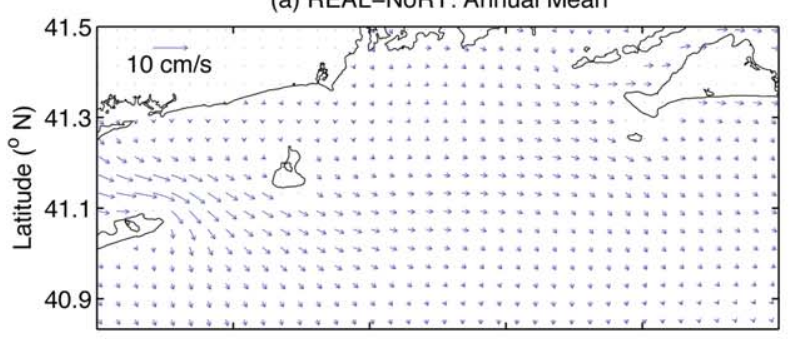

(b) REAL-NoRT: March

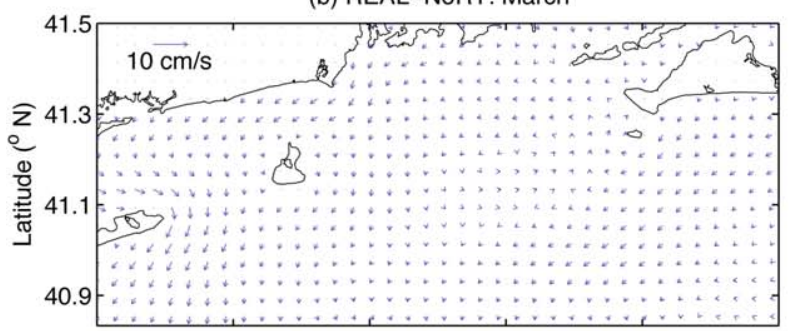

(c) REAL-NoRT: June

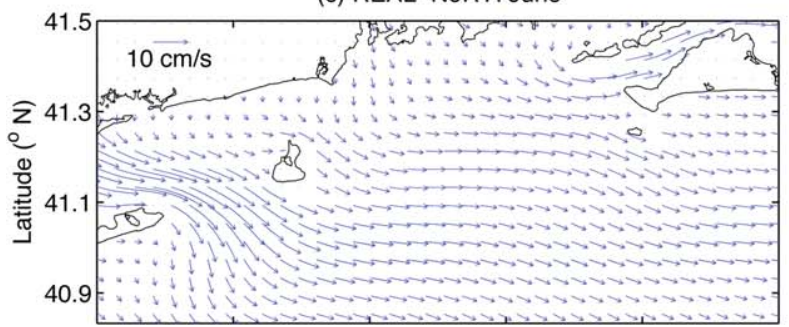

(d) REAL-NoRT: September

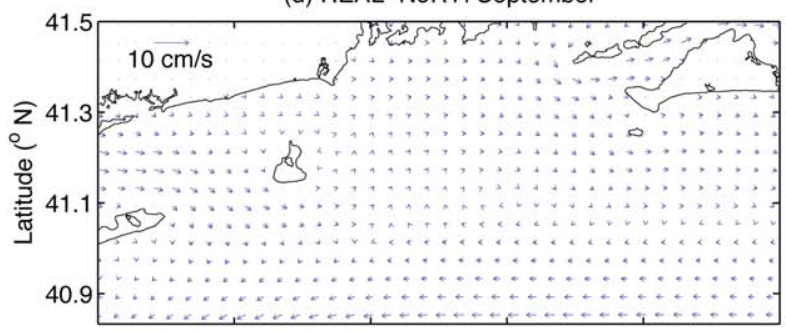

(e) REAL-NoRT: December

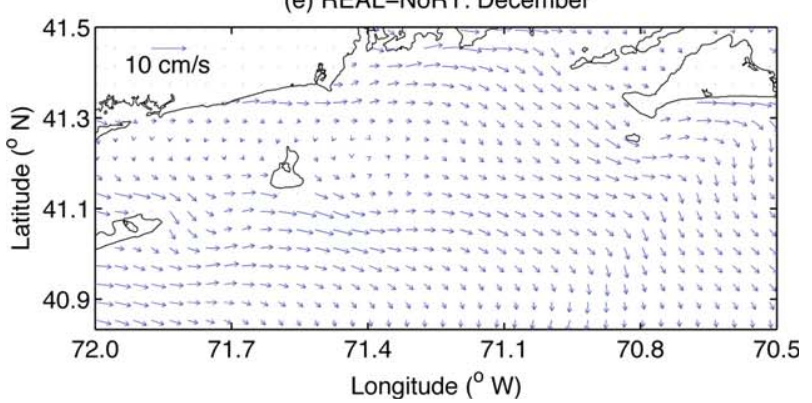

Figure 14. Same as Figure 12 but from Experiment REAL-NoRT.

along the coast (mostly from the Connecticut River) does not play an important role for the RIS circulation, but it does significantly influence the flow around Block Island as well as on the inner shelf area south of Montauk Point. (a) REAL

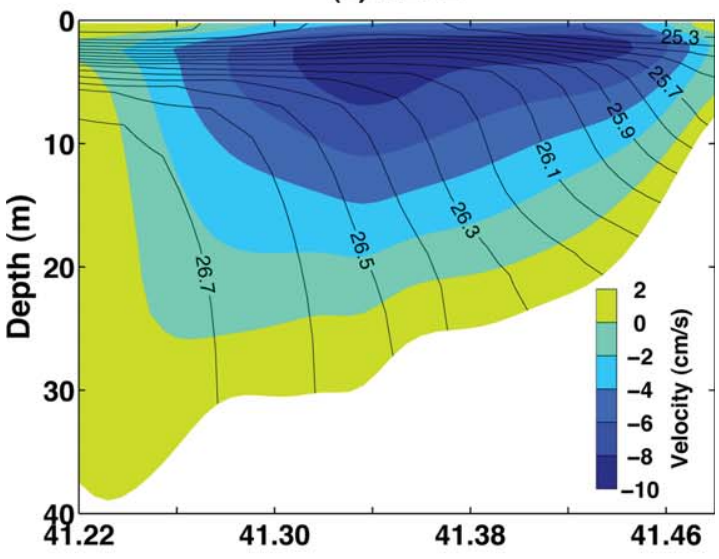

(b) REAL-NoR

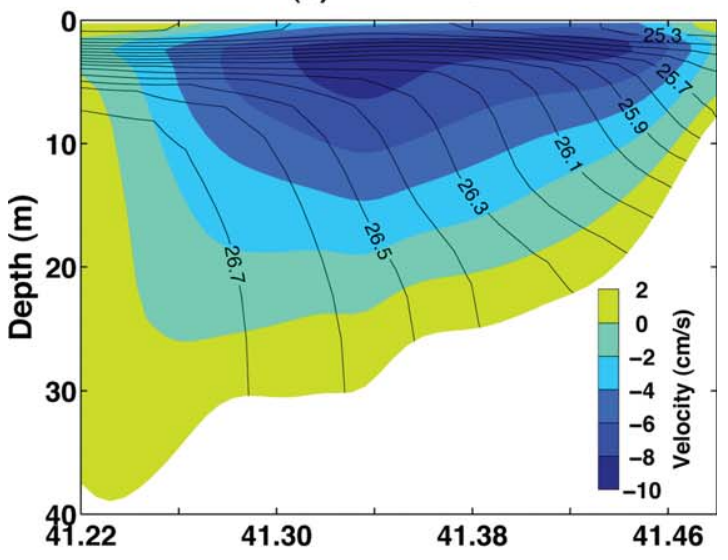

(c) REAL-NoRT

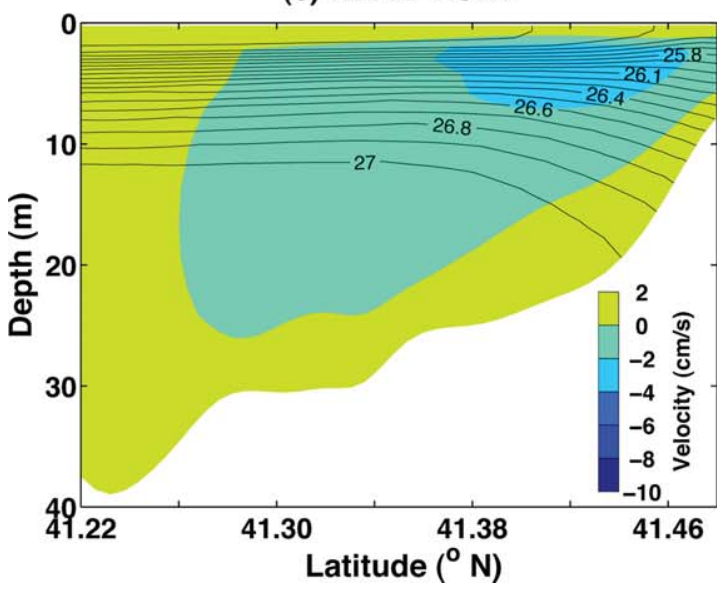

Figure 15. July density (contour interval $(\mathrm{CI})=0.1 \mathrm{~kg}$ $\mathrm{m}^{-3}$ ) and u-component velocity fields (color in $\mathrm{cm} \mathrm{s}^{-1}$ ) along a section near the northern RIS coast (see Figure 12a) from Experiments (a) REAL, (b) REAL-NoR, and (c) REAL-NoRT.

\section{Interannual Variability of the Circulation}

[34] In addition to the seasonal variability, the regional circulation has interannual changes that appear to be related to the North Atlantic Oscillation (NAO). The NAO refers 


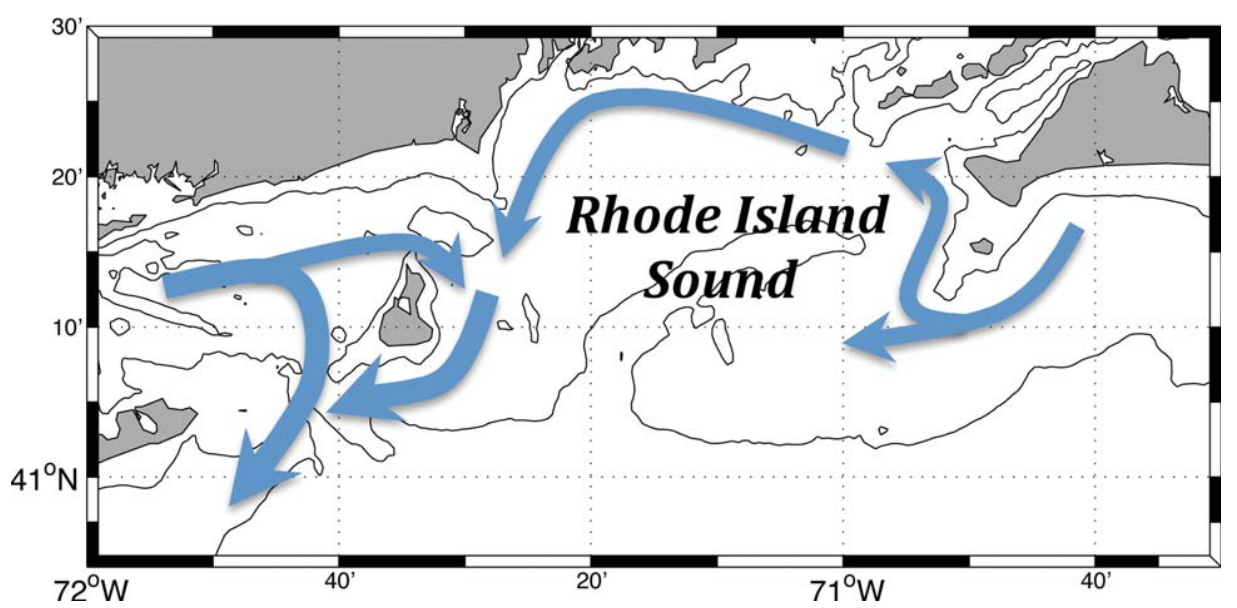

Figure 16. Schematic of the surface circulation during summer in and around the RIS.
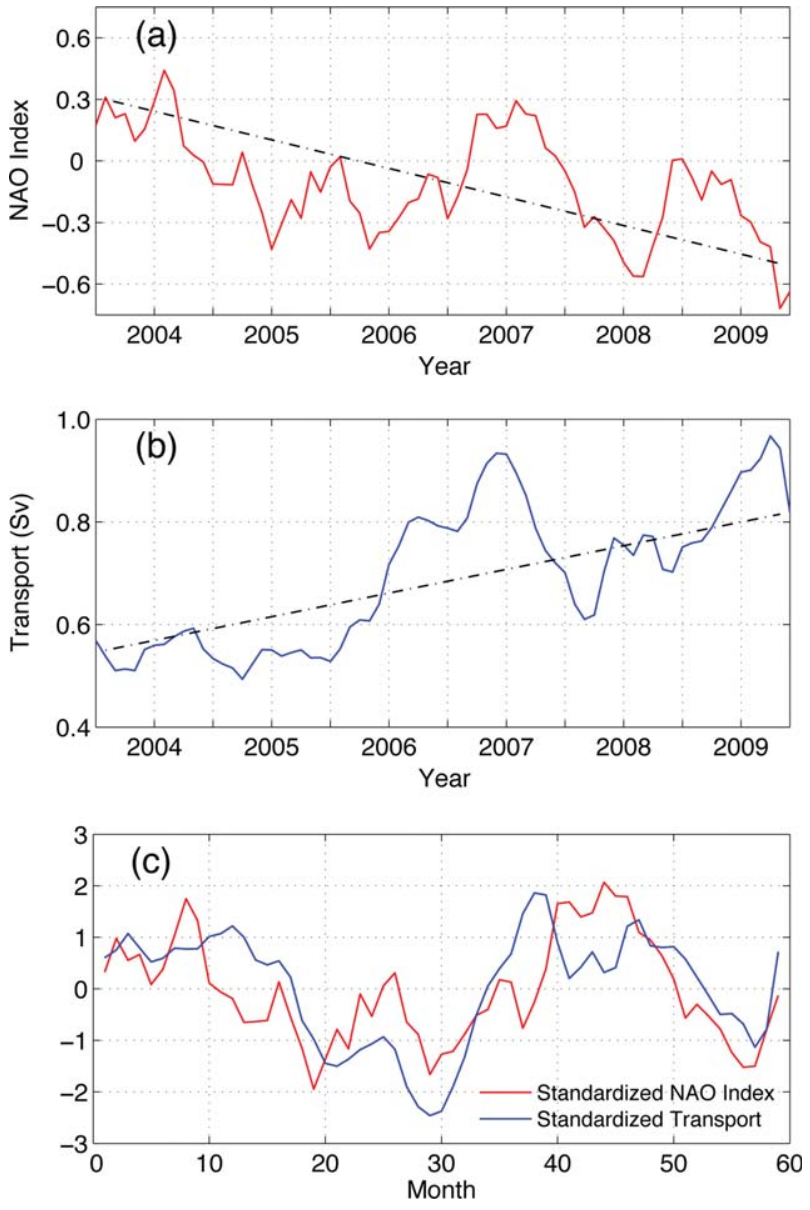

Figure 17. (a) Five month low-pass NAO index from 2004 to 2009 (data from www.cpc.noaa.gov/products/precip/CWlink/pna/norm.nao.monthly.b5001.current.ascii); (b) Five month low-pass alongshelf transport from 2004 to 2009 along a section over the southern New England shelf break (see Figure 11a) from Experiment REAL with the regional-scale ROMS; and (c) Standardized time series of the NAO index and the alongshelf transport with peakcorrelation time lag $=13$ applied and the sign of the second time series reversed. The dashed lines in Figures 17a and $17 \mathrm{~b}$ represent their trends, respectively. to a redistribution of atmospheric mass between the Arctic and subtropical Atlantic. Swings from one phase to another produce large changes to both the mean wind speed and direction over the Atlantic, and the heat and moisture transport between the Atlantic and the neighboring continents [Hurrell et al., 2003]. A gyre-scale circulation response is also likely associated with this atmospheric variability. The strength of the NAO is quantified by an index based upon the average atmospheric pressure difference between the Azores and Iceland. High (low) values of the NAO index reflect enhanced (diminished) midlatitude westerly and trade winds, with related shifts in wind patterns and intensities of air-sea exchanges of heat, freshwater, and momentum. During the period of the model integration (20042009), the NAO index fluctuated considerably (Figure 17a), with high NAO years of 2004 and 2007, and low NAO years of 2005-2006 and 2008. In addition, the index shows a falling trend during this period of time.

[35] In response to the change in surface forcing, the ocean circulation changes accordingly. There have been a number of studies investigating the circulation change in the northwestern Atlantic Ocean with different NAO phases. For example, southwestward flow along the shelf edge from the Scotian shelf to Georges Bank is observed to increase by $1-2 \mathrm{~Sv}$ during the low NAO in the 1960 s compared to the high NAO in the 1970s [Loder et al., 2001]. The Labrador Current (LC) is found to be reduced by $\sim 0.4$ $\mathrm{Sv}$ south of Newfoundland over a period of high NAO in the 1990s [Luo et al., 2006]. Effects of the NAO are also observed in the position of the north wall of the GS, which moves northward during positive phases and southward during negatives with a lag of about 1-2 years [e.g., Taylor and Stephens, 1998; Rossby and Benway, 2000; Dong and Kelly, 2003]. In addition, recent studies reveal that there is a significant correlation between near-surface transport in the GS and the NAO index [Rossby et al., 2010], as well as between GS warm-core rings and the state of the NAO [Chaudhuri et al., 2009].

[36] In this section, we focus on how the circulation over the southern New England shelf as well as the RIS responds to associated changes in surface forcing during 2004-2009. First, we select a section near the shelf break 
(a) REAL: Surface, January 2005

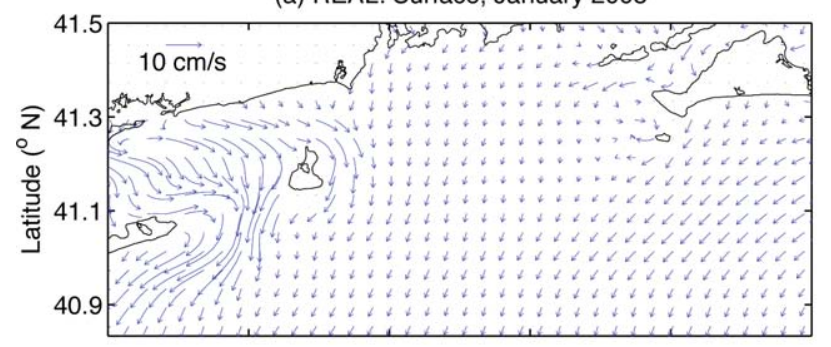

(c) REAL: Surface, January 2007

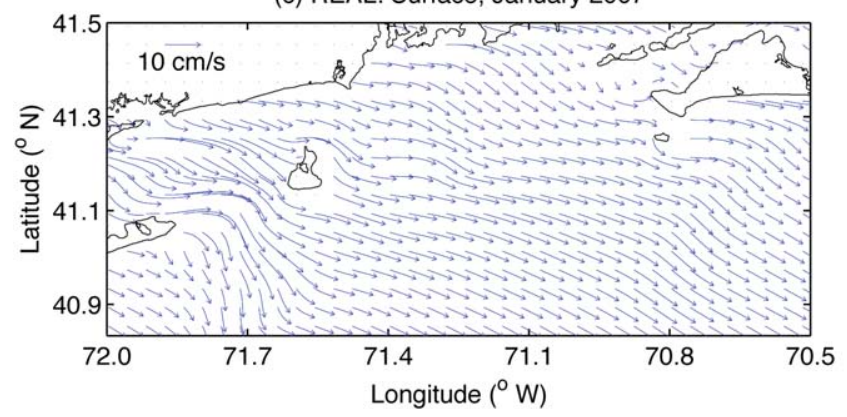

(b) REAL: Bottom, January 2005

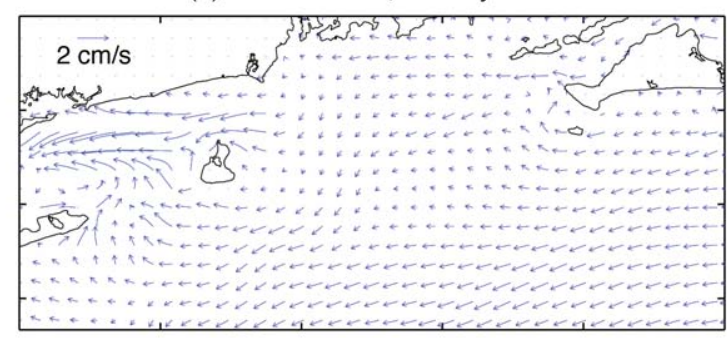

(d) REAL: Bottom, January 2007

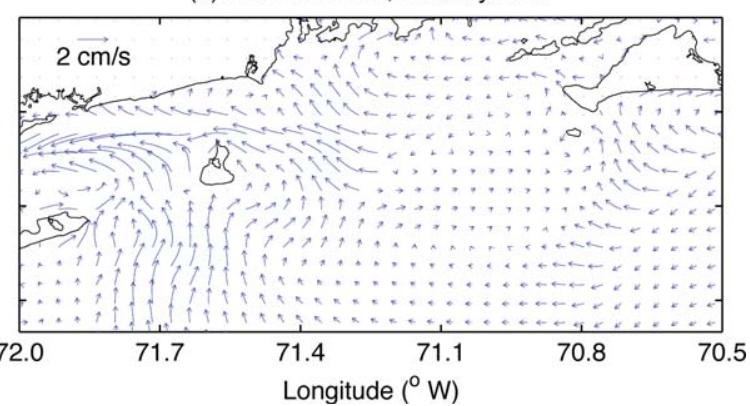

Figure 18. Velocity fields from Experiment REAL with the local-scale ROMS: (a) surface layer on January 2005, (b) bottom layer on January 2005, (c) surface layer on January 2007, and (d) bottom layer on January 2007.

(a) Wind stress: January 2005

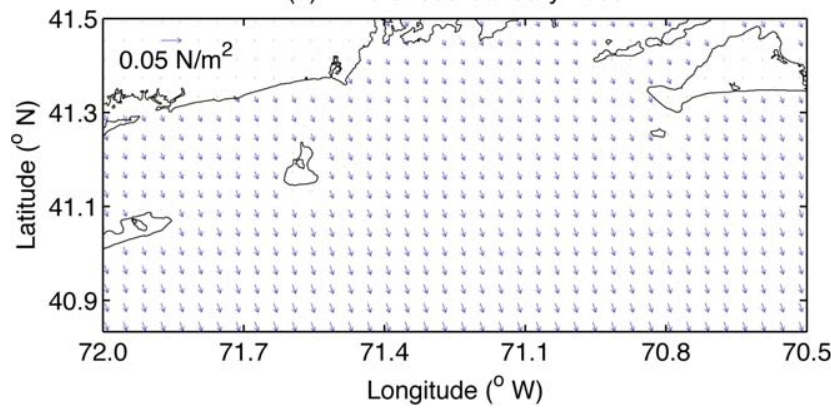

(b) Wind stress: January 2007

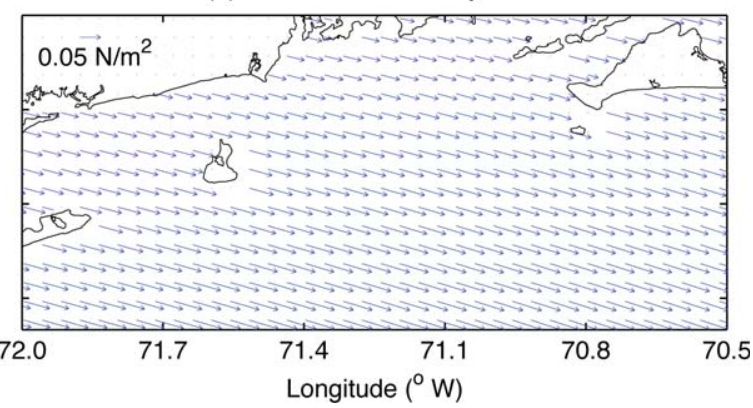

Figure 19. January wind stress fields: (a) 2005 and (b) 2007.

(a) CTRL

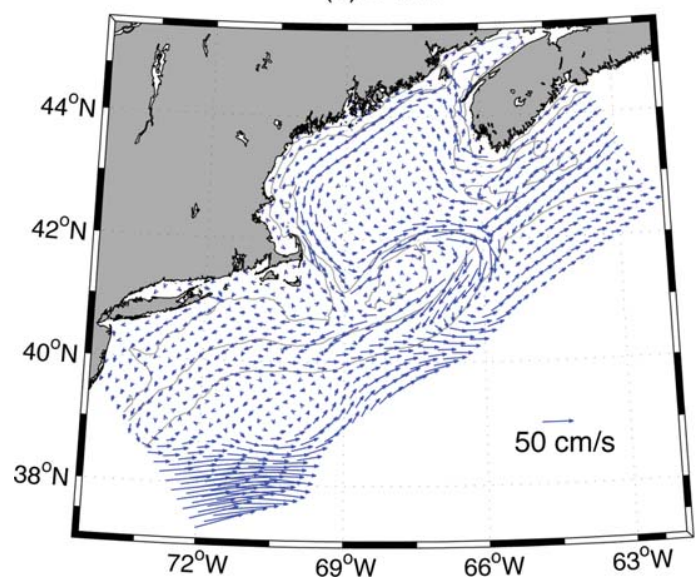

(b) WARM minus CTRL

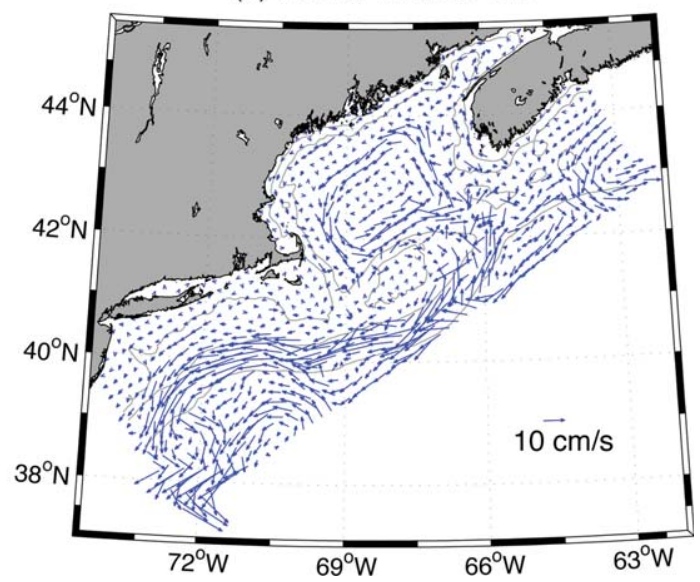

Figure 20. (a) Surface velocity in a present-day climate (CTRL) and (b) its change from a warming climate (WARM minus CTRL). The present-day climate is represented by an average over years 19912000, and the future warming climate is that over years 2091-2100. 
of southern New England (red line in Figure 11a), and calculate volume fluxes across the section (positive toward the southwest). From Figure $17 \mathrm{~b}$ we see that there is significant interannual variability in the alongshelf transport with relatively smaller values during 2005 and 2008 (corresponding to the high NAO years of 2004 and 2007; Figure 17a), and larger values during 2006-2007 and 2009 (corresponding to the low NAO years of 2005-2006 and 2008; Figure 17a). To further examine the relationship between the alongshelf transport and the NAO index, after both time series are standardized by removing their mean values and linear trends and then dividing by their standard deviations, we estimate their lagged correlation. The result shows that the correlation coefficient is highest (negatively) when the transport lags behind the index by 13 months. Figure 17c presents the two standardized time series in which the 13 month time lag is applied and the sign of time series of the transport is reversed. We find that the two lines in Figure $17 \mathrm{c}$ overlay quite well, indicating more clearly that the circulation near the shelf break intensifies (weakens) during negative (positive) phases of the NAO with a lag of 13 months. Of equal interest, the alongshelf transport appears to have a rising trend (Figure 17b), corresponding to the falling trend in the NAO index (Figure 17a). This provides additional evidence linking the response of the regional circulation in the northwest Atlantic to the NAO.

[37] Since the circulation over the MAB is closely related to the LC upstream and the GS to the south, the relationship between the NAO and the alongshelf transport can be explained by the lagged responses of the LC transport and the GS shift to the NAO. For example, associated with the low NAO index during the winter of 1996, the Labrador Slope Water was observed to extend southward along the edge of the Scotian shelf in the autumn of 1997 and reach the MAB by early 1998 [Drinkwater and Gilbert, 2004]. The presence of the Labrador Slope Water is related to the volume transport of the LC [Petrie and Drinkwater, 1993], which in turn, is related to the NAO index [Marsh et al., 1999; Drinkwater et al., 2003]. This is also demonstrated by Han [2002], who presents interannual sea level changes from the Laurentian Channel to the MAB in the 1990 s from satellite altimetry and tide-gauge data. The sea level falls rapidly in early 1997-1998 from the eastern Scotian shelf to the MAB, which is attributed to an increase in the LC transport and a southward shift in the GS position.

[38] However, such a relationship does not exist between the RIS circulation and the NAO index. Instead, the model results reveal that the circulation patterns and magnitudes in the RIS are quite different between the low and high NAO winters, and the difference is found throughout the whole water column. For example, in the winter of 2005 , the surface flows (Figure 18a) are southward and relatively sluggish $(2 \sim 3 \mathrm{~cm} / \mathrm{s})$; in the bottom layer (Figure 18b), there are westward currents originating from south of Martha's Vineyard along the inner shelf to balance these surface offshore transports. In the winter of 2007, however, the surface flows in the RIS (Figure 18c) are southeastward and very strong $(8 \sim 10 \mathrm{~cm} / \mathrm{s})$, while the replenished water in the bottom layer (Figure 18d) is largely coming from the outer shelf and moving up-shelf northward. Another significant difference is that the strong surface flow out of the BIS turns southwestward along the shelf in the winter of 2005
(Figure 18a), different from that in the winter of 2007 that turns southeastward across the shelf (Figure 18c). A look at the atmospheric forcing reveals that these circulation differences in and around the RIS can be attributed to a change in the local wind stress from one NAO phase to another according to Ekman layer dynamics. Figure 19 shows the wintertime wind stress fields for the low NAO year of 2005 (Figure 19a) and the high NAO year of 2007 (Figure 19b). The latter shows that the wind is much intensified and its direction turns to the east-southeast from the south-southeast. This result further indicates the important role of the wintertime winds for the local circulation in the RIS, supporting an opinion by Lentz [2008b].

\section{Response of the Circulation to Global Warming}

[39] Robust changes of global ocean circulation have been projected based upon coupled climate models under global warming scenarios [e.g., Meehl, et al., 2007; Vecchi and Soden, 2007; Luo et al., 2009; Collins et al., 2010; Luo and Rothstein, 2011]. However, it is less clear how the regional ocean circulation responds to global warming. In this section, a dynamical downscaling approach is adopted in which global climate model outputs are used to provide atmospheric forcing and ocean open boundary conditions for both the present-day climate and the future warmer climate experiments with the ROMS models, and the differences between their solutions are identified as the response of the regional ocean circulation to global warming. Note that, since the global climate model has a relatively coarse resolution in both its atmosphere and ocean components, we do not expect that the ROMS model here will accurately reproduce in as much detail as did the realistic simulations from 2004 to 2009 (which used more highly resolved ocean open boundary conditions and atmospheric fluxes). We therefore focus attention on only the major features of the regional ocean circulation and investigate how those circulation features will change in a warmer climate.

[40] Figure 20 shows the surface circulation in the present-day climate and its response to global warming. It can be seen from Figure 20a that the model does capture the important features of the circulation including the cyclonic circulation in the Gulf of Maine, the anticyclonic circulation around the Georges Bank, and the southwestward alongshelf flow on the southern New England shelf as well as the GS although it appears further north than reality which is common to models with coarse resolution [Smith et al., 2000]. As the climate warms (Figure 20b), it is found that the modeled changes in the regional ocean circulation exhibit a spatial pattern that is suggestive of more negative NAO-like conditions such as a strengthening or expanding of the cyclonic circulation in the Gulf of Maine, a speedup of the anticyclonic circulation around the Georges Bank, an intensification of the southwestward currents over the southern New England shelf and slope, and a weakening or a southward movement of the GS.

[41] A closer look at the open boundary and surface forcing suggests that these changes in the regional ocean circulation can be attributed to a combination of changes in the remote forcing from the open boundary and in the local surface heat fluxes. Comparing the future climate (Figure 21b) 
(a) CTRL

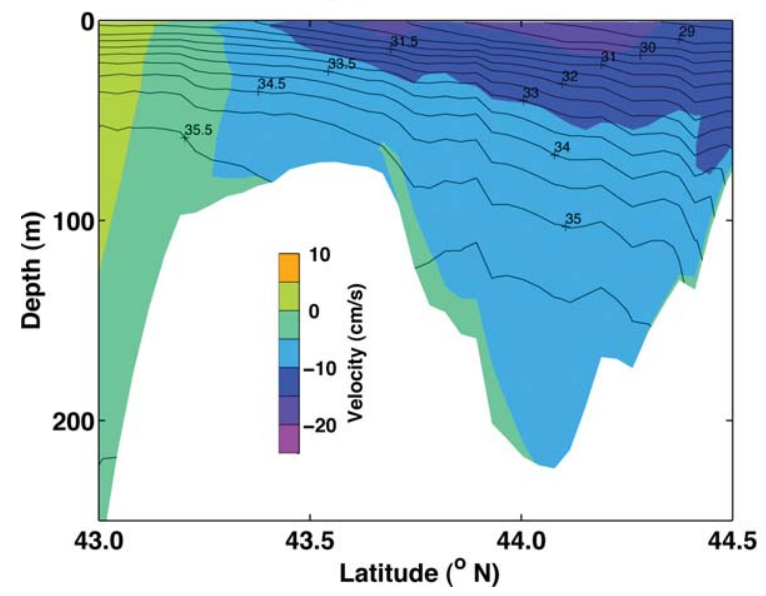

(b) WARM

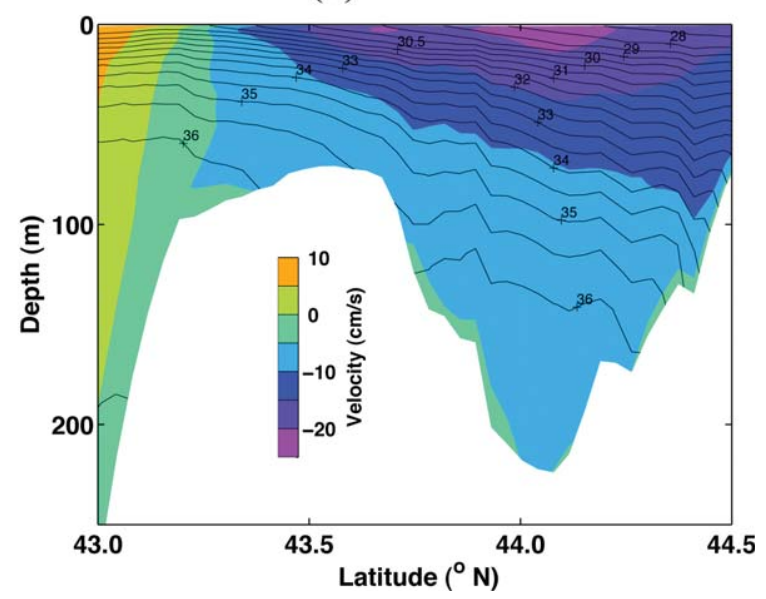

Figure 21. Salinity $(\mathrm{CI}=0.5 \mathrm{psu})$ and $\mathrm{u}$-component velocity (color in $\mathrm{cm} \mathrm{s}^{-1}$; negative toward the southwest into the region) along the eastern boundary of the regional-scale ROMS in Experiments (a) CTRL and (b) WARM.

(a) Heat flux change

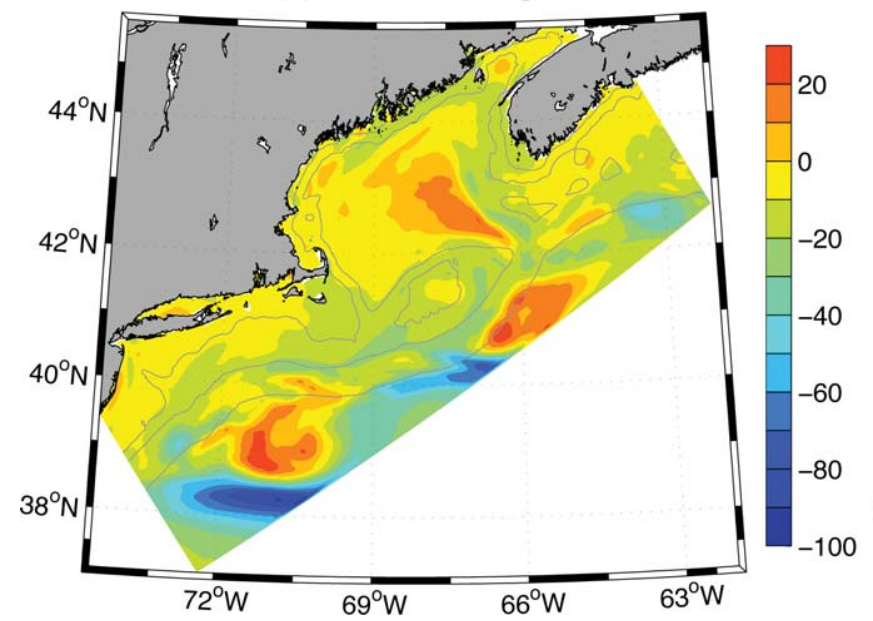

(b) Wind stress change

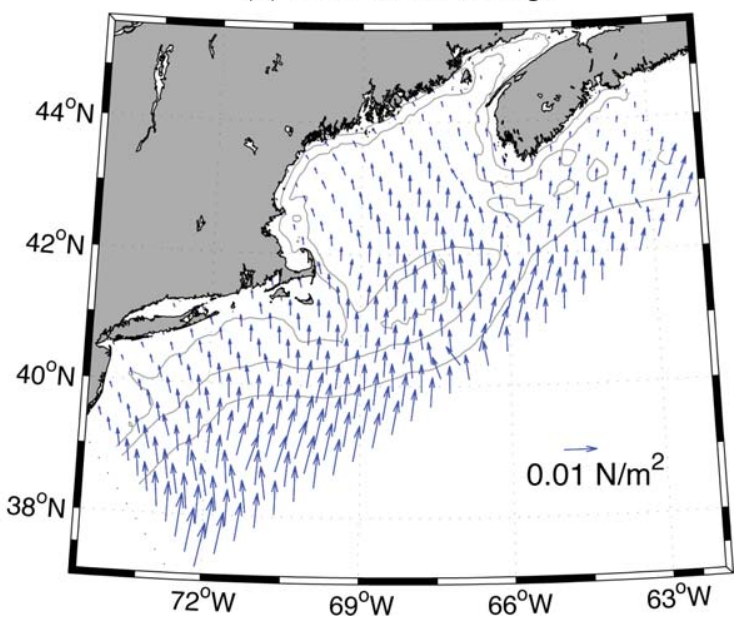

Figure 22. Differences of (a) ocean-to-atmosphere heat flux (color in $\mathrm{W} \mathrm{m}^{-2}$ ) and (b) wind stress $\left(\mathrm{N} \mathrm{m}^{-2}\right)$ between the two scenarios (SRESA1B minus 20C3M).

to the present-day climate (Figure 21a), the southwestward coastal flow across the eastern boundary of the regionalscale model is found to be significantly stronger, with its volume transport increasing by $0.4 \mathrm{~Sv}$ or $18 \%$ from $2.2 \mathrm{~Sv}$ in the present-day climate to $2.6 \mathrm{~Sv}$ in the future climate. This intensified flow carries fresher water along the coast into the region, with a minimum salinity of $\sim 29$ psu in the presentday climate but only $\sim 28 \mathrm{psu}$ in the future climate. In the warming climate, on the other hand, more heat released from the ocean to the atmosphere around the center of the Gulf of Maine (Figure 22a) will result in accelerating the geostrophic current along the coast, i.e., strengthening the cyclonic circulation in the Gulf of Maine. However, global warming induces a roughly northward wind stress change over the region (Figure 22b) that may not contribute directly to the changes of those current systems described above.

[42] Under the warmer climate scenario, the cyclonic gyre in the RIS is also found to be intensified, with the maximum velocity near the northern RIS coast being increased by $\sim 1 \mathrm{~cm} / \mathrm{s}$ or $33 \%$ from $\sim 3 \mathrm{~cm} / \mathrm{s}$ in $20 \mathrm{C} 3 \mathrm{M}$ to $\sim 4 \mathrm{~cm} / \mathrm{s}$ in SRESA1B (not shown). Since there is no significant change in the local forcing (both wind stress and heat flux) from 20C3M to SRESA1B, the stronger cyclonic circulation in the RIS is believed to be caused by the remote forcing, i.e., by the intensification of the larger-scale coastal ocean circulation over the southern New England shelf in the warming climate.

\section{Summary}

[43] It has been observed that there is a jet-like current near the northern RIS coast that is stronger in summer and disappears in winter. To investigate the variability of the RIS circulation and to understand the processes that cause that variability we have used ROMS with two configurations for which a local-scale model with very fine resolution over the RIS is nested into a regional-scale model 
covering the entire US Northeastern Continental Shelf. Model solutions are first compared to observations, suggesting that the model is reliable for examining the mean circulation and its variability over the southern New England shelf and coastal regions.

[44] Results from our model experiment hierarchy indicate that there exists a cyclonic circulation within the RIS during summer, resulting from a combination of tidal forcing and density differences between coastal and interior regions that are balanced by a geostrophic flow. In winter, the northwesterly winds turn the surface flows offshore. The freshwater discharge from the rivers along the coast does not play an important role for the RIS circulation, but it does significantly influence the flows around Block Island as well as on the inner shelf area south of Montauk Point.

[45] In addition to the seasonal variability, our simulations also show that the RIS circulation has interannual changes that appear to be related to the NAO. During the low (high) NAO winter, the surface flows are weak (strong) toward the south (southeast) while the replenished water in the bottom layer is largely westward (northward). These differences are primarily due to the difference in the local winds between the two NAO phases. In addition, the southwestward jet near the southern New England shelf break intensifies (weakens) during the low (high) phases of the NAO with a lag of about 1 year. From 2004 to 2009, meanwhile, its volume transport is found to have a rising trend, corresponding to a falling trend in the NAO index.

[46] We have extended our experiments to investigate the changes in the circulation under a warming climate. For these experiments we have used atmospheric forcing and open boundary conditions from global climate model outputs. We find that global warming will induce a stronger cyclonic circulation in the RIS that is the result of an intensification of the larger-scale coastal ocean circulation over the southern New England shelf. In addition, as the climate warms significant changes of the regional circulation also consists of a speedup of both the cyclonic circulation in the Gulf of Maine and the anticyclonic circulation around the Georges Bank. These can be traced to an intensified coastal inflow from the eastern open boundary of the regionalscale model as well as an enhanced ocean-to-atmosphere heat release around the center of the Gulf of Maine associated with a warming climate.

[47] Acknowledgments. Dave Ullman (University of Rhode Island), Dan Codiga (University of Rhode Island), and Steven Lentz (Woods Hole Oceanographic Institution) graciously shared their observational data with us. We acknowledge the international modeling groups for providing their data for analysis, and the PCMDI and the IPCC Data Archive at Lawrence Livermore National laboratory for collecting, archiving, and making the data available. This manuscript was significantly improved by the comments of two anonymous reviewers. Y. Luo would like to acknowledge the support from the Zhufeng and Taishan Projects of the Ocean University of China. This work is supported by the URI Regional Earth Systems Center (RESC) through DOE grant DE-SC0005432.

\section{References}

Beardsley, R. C., and W. C. Boicourt (1981), On estuarine and continental shelf circulation in the Middle Atlantic Bight, in Evolution in Physical Oceanography, edited by B. A. Warren and C. Wunsch, pp. 198-233, MIT Press, Cambridge, Mass.
Beardsley, R. C., D. C. Chapman, K. H. Brink, S. R. Ramp, and R. Schlitz (1985), The Nantucket Shoals Flux Experiment (NSFE79), Part 1: A basic description of the current and temperature variability, J. Phys. Oceanogr., 15, 713-748.

Brooks, D. A. (1985), Vernal circulation in the Gulf of Maine, J. Geophys. Res., 92, 8183-8196.

Chapman, D. C., and R. C. Beardsley (1989), On the origin of shelf water in the Middle Atlantic Bight, J. Phys. Oceanogr., 19, 384-391.

Chaudhuri, A. H., J. J. Bisagni, and A. Gangopadhyay (2009), Shelf water entrainment by Gulf Stream warm-core rings between $75^{\circ} \mathrm{W}$ and $50^{\circ} \mathrm{W}$ during 1978-1999, Cont. Shelf Res., 29, 393-405.

Chen, K., and R. He (2010), Numerical investigation of the Middle Atlantic Bight shelfbreak frontal circulation using a high-resolution ocean hindcast model, J. Phys. Oceanogr., 40, 949-964.

Codiga, D. L. (2009), Circulation in Block Island Sound, Rhode Island Sound, and adjacent waters, with emphasis on subsurface flows, paper presented at the 7th Annual Ronald C. Baird Sea Grant Science Symposium on Sound Connections: The Science of Rhode Island and Block Island Sounds, sponsored by Rhode Island Sea Grant, Block Island, RI.

Codiga, D. L., and L. V. Rear (2004), Observed tidal currents outside Block Island Sound: Offshore decay and effects of estuarine outflow, J. Geophys. Res., 109, C07S05, doi: 10.1029/2003JC001804.

Codiga, D. L., and D. S. Ullman (2010), Characterizing the physical oceanography of coastal waters off Rhode Island, Part 1: Literature review, available observations, and a representative model simulation, in Appendix to Rhode Island Ocean Special Area Management Plan, pp. 1-170, University of Rhode Island, Kingston, RI.

Collins, M., et al. (2010), The impact of global warming on the tropical Pacific Ocean and El Nino, Nat. Geosci., 3, 391-397, doi: 10.1038/ ngeo868.

Cowles, G. W., S. J. Lentz, C. Chen, Q. Xu, and R. C. Bearsley (2008), Comparison of observed and model-computed low frequency circulation and hydrography on the New England shelf, J. Geophys. Res., 113, C09015, doi: 10.1029/2007JC004394.

Dickey, T., and A. J. Williams III (2001), Interdisciplinary ocean process studies on the New England shelf, J. Geophys. Res., 106, 9427-9434.

Dong, S., and K. A. Kelly (2003), Seasonal and interannual variations in geostrophic velocity in the Middle Atlantic Bight, J. Geophys. Res., 108(C6), 3172, doi: 10.1029/2002JC001357.

Drinkwater, K., and D. Gilbert (2004), Hydrographic variability in the waters of the Gulf of St. Lawrence, the Scotian shelf and the eastern Gulf of Maine (NAFO subarea 4) during 1991-2000, J. Northw. Atl. Fish. Sci., 34, 83-99.

Drinkwater, K., B. Petrie, and P. C. Smith (2003), Climate variability on the Scotian shelf during 1990s, ICES Mar. Sci. Symp., 219, 40-49.

Edwards, C. A., T. A. Fake, and P. S. Bogden (2004), Spring-summer frontogenesis at the mouth of Block Island Sound: 1. A numerical investigation into tidal and buoyancy-forced motion, J. Geophys. Res., 109, C12021, doi: 10.1029/2003JC002132.

Flather, R. A. (1976), A tidal model of the northwest European continental shelf, Mem. Soc. R. Sci. Liége, 6, 141-164.

Fratantoni, P. S., and R. S. Pickart (2003), Variability of the shelf break jet in the Middle Atlantic Bight: Internally or externally forced?, J. Geophys. Res., 108(C5), 3166, doi: 10.1029/2002JC001326.

Fong, D. A., and W. R. Geyer (2002), The alongshore transport of freshwater in a surface trapped river plume, J. Phys. Oceanogr., 32, 957-972.

Han, G. (2002), Interannual sea-level variations in the Scotian-Maine region in the 1990s, Can. J. Remote Sens., 28, 581-587.

He, R., and R. H. Weisberg (2002), West Florida shelf circulation and temperature budget for the 1999 spring transition, Cont. Shelf Res., 22, 719-748.

He, R., and J. L. Wilkin (2006), Barotropic tides on the southwest New England shelf: A view from a hybrid data assimilative modeling approach, J. Geophys. Res., 111, C08002, doi: 10.1029/2005JC003254.

Houghton, R.W., F. Aikman III, and H.W. Ou (1988), Shelf-slope frontal structure and cross-shelf exchange at the New England shelf break, Cont. Shelf Res., 8, 687-710.

Hurrell, J. W. (1995), Decadal trends in the North Atlantic Oscillation: Regional temperatures and precipitation, Science, 269, 676-679.

Hurrell, J. W., Y. Kushnir, G. Ottersen, and M. Visbeck (Eds.) (2003), The North Atlantic Oscillation: Climatic Significance and Environmental Impact, Geophys. Monogr. Ser. 134, pp. 1-279, AGU, Washington, D. C., doi: 10.1029/GM134.

Ingham, M. C., et al. (1982), Summary of physical oceanographic processes and features pertinent to pollution distribution in the coastal and offshore waters of the northeastern United States, Virginia to Maine, 


\section{LUO ET AL.: CIRCULATION IN THE RHODE ISLAND SOUND}

166 pp., Northeast Fish. Cent., Natl. Mar. Fish. Serv., NOAA, U.S. Dep. of Commer., Woods Hole, Mass.

Kincaid, C., R. A. Pockalny, and L. M. Huzzey (2003), Spatial and temporal variability in flow at the mouth of Narragansett Bay, J. Geophys. Res., 108(C7), 3218, doi: 10.1029/2002JC001395.

Lentz, S. J. (2008a), Observation and a model of the mean circulation ove the Middle Atlantic Bight Continental Shelf, J. Phys. Oceanogr., 38 , $1203-1221$.

Lentz, S. J. (2008b), Seasonal variability in the circulation over the Middle Atlantic Bight Continental Shelf, J. Phys. Oceanogr., 38, 1486-1500.

Linder, C. A., and G. Gawarkiewicz (1998), A climatology of the shelfbreak front in the Middle Atlantic Bight, J. Geophys. Res., 103, 18,40518,423 .

Loder, J. W., J. A. Shore, C. G. Hannah, and B. D. Petrie (2001), Decadalscale hydrographic and circulation variability in the Scotia-Marine region, Deep Sea Res., Part II, 48, 3-35.

Luettich, R. A., J. J. Westerink, and N. W. Scheffner (1992), ADCIRC: An advanced three-dimensional circulation model for shelves, coasts and estuaries, Report 1: Theory and Methodology of ADCIRC-2DDI and $A D C I R C-3 D L$, Tech. Rep. DRP-92-6, Dep. of the Army, U.S. Army Corps of Eng., Washington, D. C.

Luo, Y., and L. M. Rothstein (2011), Response of the Pacific Ocean circulation to climate change, Atmos. Ocean, 49, 235-244, doi: 10.1080/ 07055900.2011.602325.

Luo, Y., M. D. Prater, E. G. Durbin, and L. M. Rothstein (2006), Changes in the northwest Atlantic circulation for the 1992-95 high NAO period from a numerical model, Cont. Shelf Res., 26, 1617-1635.

Luo, Y., Q. Liu, and L. M. Rothstein (2009), Simulated response of North Pacific mode waters to global warming, Geophys. Res. Lett., 36, L23609, doi: 10.1029/2009GL040906.

Marsh, R., B. Petrie, C. R. Weidman, R. R. Dickson, J. W. Loder, C. G. Hannah, K. Frank, and K. Drinkwater (1999), The 1882 tilefish kill-A cold event in shelf waters off the northeastern United States?, Fish. Oceanogr., 8, 39-49.

Mau, J.-C., D.-P. Wang, D. S. Ullman, and D. L. Codiga (2007), Comparison of observed (HF radar, ADCP) and model barotropic tidal currents in the New York Bight and Block Island Sound, Cont. Shelf Res., 72, 129137.

Meehl, G. A., et al. (2007), Global climate projections, Contribution of Working Group I to the Fourth Assessment Report of the IPCC, in Climate Change 2007: The Physical Science Basis, edited by S. Solomon et al., pp. 1-996, Cambridge Univ. Press, Cambridge, United Kingdom.

Moody, J. A., et al. (1984), Atlas of tidal elevation and current observations on the Northeast American continental shelf and slope, U.S. Geol. Surv. Bull., 1611, 122.

Mountain, D. G. (2003), Variability in the properties of shelf water in the Middle Atlantic Bight, 1977-1999, J. Geophys. Res., 108(C1), 3014, doi: 10.1029/2001JC001044

Myers, R. A., S. A. Akenhead, and K. Drinkwater (1990), The influence of Hudson Bay runoff and ice-melt on the salinity of the inner Newfoundland Shelf, Atmos. Ocean, 28, 241-256.
Nixon, S. W., S. Granger, B. A. Buckley, M. Lamont, and B. Rowell (2004), A one hundred and seventeen year coastal temperature record from Woods Hole, Massachusetts, Estuaries, 27, 397-404.

Oey, L.-Y., J. Manning, H. T. Jo, and K. W. You (1995), A plume and wind-driven circulation model of the New York Bight, Quantitative Skill Assessment for Coastal Ocean Models, in Coastal and Estuarine Studies, vol. 41, edited by D. R. Lynch and A. M. Davies, pp. 329-348, AGU, Washington, D. C.

Oviatt, C. A. (2004), The changing ecology of temperate coastal waters during a warming trend, Estuaries, 27, 895-904.

Petrie, B., and K. Drinkwater (1993), Temperature and salinity variability on the Scotian shelf and in the Gulf of Maine 1945-1990, J. Geophys. Res., 98, 20, 079-20,089.

Pingree, R. D., and L. Maddock (1979), The tidal physics of headland flows and offshore tidal bank formation, Mar. Geol., 32, 269-289.

Rio, M.-H., and F. Hernadez (2004), A mean dynamic topography computed over the world ocean from altimetry, in situ measurements, and a geoid model, J. Geophys. Res., 109, C12032, doi: 10.1029/ 2003JC002226.

Rossby, T., and R. L. Benway (2000), Slow variations in mean path of the Gulf Stream east of Cape Hatteras, Geophys. Res. Lett., 27, 117-120.

Rossby, T., C. Flagg, and K. Donohue (2010), On the variability of Gulf Stream transport from seasonal to decadal timescales, J. Mar. Res., 68 , 503-522.

Saha, S., et al. (2010), The NCEP climate forecast system reanalysis, Bull. Am. Meteorol. Soc., 91, 1015-1057, doi: 10.1175/2010BAMS3001.1.

Sankaranarayanan, S. (2007), Modeling the tide and wind-induced circulation in Buzzards Bay, Estuarine Coastal Shelf Sci., 73, 467-480.

Shearman, R. K., and S. J. Lentz (2003), Dynamics of mean and subtidal flow on the New England shelf, J. Geophys. Res., 108(C8), 3281, doi: 10.1029/2002JC001417.

Smith, R. D., M. E. Maltrud, F. O. Bryan, and M. W. Hecht (2000), Numerical simulation of the North Atlantic Ocean at $1 / 10^{\circ}, J$. Phys. Oceanogr., $30,1532-1561$

Steward, R. H. (2008), Introduction of Physical Oceanography, 353 pp., Orange Grove Texts Plus, Gainesville, Florida.

Sullivan, M. C., R. K. Cowen, and B. P. Steves (2005), Evidence for atmospheric-ocean forcing of yellowtail flounder (Limanda ferruginea) recruitment in the Middle Atlantic Bight, Fish. Oceanogr., 14, 386-399.

Taylor, A. H., and J. A. Stephens (1998), The North Atlantic Oscillation and the latitude of the Gulf Stream, Tellus, Ser. A, 50, 134-142.

Ullman, D. S., and D. L. Codiga (2004), Seasonal variation of a coastal jet in the Long Island Sound outflow region based on HF radar and Doppler current observations, J. Geophys. Res., 109, C07S06, doi: 10.1029/ 2002JC001660.

Vecchi, G. A., and B. J. Soden (2007), Global warming and the weakening of the tropical circulation, J. Clim., 20, 4316-4340.

Wilkin, J. L. (2006), The summertime heat budget and circulation of southeast New England shelf waters, J. Phys. Oceanogr., 36, 1997-2011.

Zhang, W. G., G. G. Gawarkiewicz, and D. J. McGillicuddy Jr. (2011), Climatological mean circulation at the New England shelf break, J. Phys. Oceanogr., 41, 1874-1893. 